\title{
The commercialisation of emerging energy technologies: the strategic alliances of high-technology entrepreneurial firms
}

\author{
Margarida Fontes \\ LNEG/UMOSE \\ margarida.fontes@lneg.pt \\ Cristina de Sousa \\ DINAMIA-CET/ISCTE-IUL \\ cristina.sousa@iscte.pt \\ Silvana Pimenta \\ ISCTE-IUL \\ silvanapimenta@netcabo.pt
}




\section{The commercialisation of emerging energy technologies: the strategic alliances of high- technology entrepreneurial firms ${ }^{1}$}

\section{Introduction}

Research on new renewable energy technologies has increased significantly in the last decade driven by the need to answer to growing environmental problems and to the expected future constraints in the supply of fossil fuel energy resources. A substantial part of this research is taking place in universities and public research organisations, often in the context of multidisciplinary teams that draw on - and sometimes combine - knowledge from a variety of fields (chemistry, physics, materials, biology, nano-sciences, electronics, computing, economics, etc). Some of this research is still far from application, but has increasingly generated technologies that address (directly or indirectly) critical aspects of energy production and supply. While some applied research - both on renewable energy technologies and on the solution of distribution problems created by their introduction - is conducted in collaboration with large established energy firms, opportunities have also started to arise for the creation of independent research-based spin-off firms that exploit advanced technologies with commercialisation potential.

The objective of this paper is exactly to look at the conditions in which firms exploiting renewable energy technologies (based on wind, solar and ocean sources) develop and commercialise their technologies in the particular context of the electricity production sector.

The literature on technological entrepreneurship has shown that new firms originating from research need to establish a variety of relationships, in order to transform their technologies in products and introduce them in the market (Elfring and Hulsink, 2003). These relationships enable firms to identify a business opportunity, to gain access to critical resources and competences and to build legitimacy (Johanisson, 1998). In the particular case of emerging technologies, the literature shows that often the actual opportunity and even some of the resources required to exploit it are shaped and reconfigured over time, through the interaction with a variety of external actors (Garud and Karnoe, 2003). The entrepreneurial process is therefore deeply embedded in the social context in which the firm is created. Thus, the technological and business environment has a strong impact on the conditions in which the new firm is created and develops, both because it influences the nature of opportunities and the type of resources and competences needed/available, and because it influences the establishment of the relationships that are critical for the entrepreneurial process (Welter, 2011).

\footnotetext{
${ }^{1}$ This paper draws on the research carried out within the Project TESS funded by FCT - Fundação para a Ciência e a Tecnologia, Portugal.
} 
Firms that develop renewable energy technologies and target the electricity generation sector are confronted with a very particular environment, which is likely to influence their exploitation strategies and the nature of the relationships that can be established for this purpose. The electricity production and distribution sector is highly complex, encompassing a range of activities associated with the generation, transmission and distribution of a resource that is central for the functioning of modern societies. Until recently it was a technologically mature and highly centralised sector dominated by large public utilities (Jacobsson and Bergek, 2004). Recent changes associated with the liberalisation of energy markets and with environmental concerns led to profound changes in the sector configuration and structure of power (which are still on-going) and opened-up opportunities for new entrants, namely in the new renewable segments (Verbong and Geels, 2007). But the sector retains a highly centralised and infrastructural nature and it is still largely dominated by large established firms, both old utilities (that reconfigured their activities) and new entrants. This is also the case in the more mature renewable energy segments that already developed an industrial structure. Less mature fields that are still characterised by high technological uncertainty and where markets are still to be created, show different configurations.

On the other hand, the energy sector - and in particular the renewable segments - are profoundly influenced by public policies and, to some extent, by countries' endowment on renewable energy sources. Thus institutional environments at country level can vary substantially, even if national strategies are increasingly affected by the behaviour of world markets and the conduct of large multinational companies (Jäger-Waldau et al, 2011). This may give rise to different opportunities, and also barriers, for new entrepreneurial entrants.

The literature - in particular the various streams of "regime transition" literatures (Geels. 2002; Hekkert et al, 2007) - have extensively addressed the nature and dynamics of the energy and /or electricity sector and the systemic mechanisms underlying its transition to a sustainable regime, associated with the introduction of renewable sources. But there is limited research on the micro-level aspects related with the behaviour of individual firms (Makard and Truffer, 2008). Moreover, although some of this literature has addressed entrepreneurs and technology-based start-ups as key elements in a transition process (Hekkert and Negro, 2009) and put forward some generic strategies regarding their potential roles in the transition process (Schot and Geels, 2007; Raven, 2007), we still know considerably less about the actual strategies of entrepreneurial firms (Wustenhagen and Wuebker, 2011), their interactions with other elements of the system (Musiolik and Markard, 2011) and, more generally, about the impact of the conditions found in the energy environment on the formation and behaviour of research-based firms. 
This research intends to provide some contribution towards this gap, by focusing on the strategies and relational behaviour of entrepreneurial, research-based start-ups. It addresses the process of creation and early development of firms that are exploiting new renewable energy technologies in a range of energy fields, investigating the process of development and commercialisation of the new technologies and the nature of the relationships established for this purpose. The objective is to gain a better understanding of firms' strategies as well as the impact of this specific environment on their definition and deployment. Given the nature of the sector, particular focus is put on the interaction with large incumbents and on their attitudes towards the new technologies being introduced by research-intensive start-ups.

For this purpose we draw on contributions from the transitions literature that provide insights into sector dynamics, as well as on the changes that took place or are underway and the opportunities they might have generated for research-based companies. We combine it with contributions from the technological entrepreneurship literature that addresses the conditions of exploitation of new technologies. Given the nature of the sector, research focusing on the relations between new entrants and powerful incumbents in contexts where changes in the knowledge base and fast technological development lead the latter to become interested in emerging technologies (Gans and Stern, 2003), is particularly relevant. Finally, we draw on literature on social networks and their relationship with entrepreneurship (Slotte-Kock and Coviello, 2009), which offers important theoretical and methodological insights into the nature of networks and their roles the early development of new firms.

Insights from this literature enable us to raise a number of questions regarding the process of commercialisation of new renewable energy technologies conducted by research-based spin-offs and the interaction with the technological and business environment: Which are the types of relationships that are established by new firms originating from research in the process commercial exploitation of advanced energy technologies? What types of actors play a role and which are theses roles? In particular, which is the position of incumbents relatively to firms' activities and what type of relationships are established between the new firm and established players? What is the influence of these relationships in the entrepreneurial process? Are there differences between technologies in different stages of development regarding the conduction of these processes?

These questions are empirically tested in the case of Portugal. In the last decade Portugal invested strongly in the development of renewable energies, both at the research and at the industrial level. This was associated with the introduction of a favourable incentive regime for the production and use of energy from renewable sources. As a result Portugal is currently positioned among the European countries with a greater penetration of renewable energy in electricity production and also with more 
ambitious targets regarding the future development of these sources (MEID, 2010). The favourable environment thus generated led to a recent upsurge in the creation of research-based firms exploiting advanced energy or energy-related technologies, which are the object of this empirical research.

In this paper we present some first results of an exploratory analysis of a small set of cases, drawing some preliminary conclusions and defining some directions for further research. This exploratory research is based on case studies of a small group of firms active in a range of non-carbon based renewable energy technologies ${ }^{2}$ in different stages of development: high-altitude wind, waves, offshore wind, solar photovoltaic (PV), on-shore wind. The analysis of these cases offer a first approach to entrepreneurs/firms early activities and relationships, the contributions of different actors, the position of incumbents, as well as to the differences between (and within) the various renewable energy segments.

\section{The role of networks in technology-based entrepreneurship}

The literature on entrepreneurship has shown that new firm creation is a complex and dynamic process, that is influenced by a variety of factors of a very diverse nature (economic, social, cultural) and strongly embedded in the environment in which it takes place (Johannisson, 1998). According to this literature, the process of firm creation and early development is shaped - facilitated and constrained - by the relationships established by the entrepreneurs with their environment and by the nature of the institutional environment in which the process takes place. These relationships are instrumental to identify/shape the opportunity (Anderson et al, 2007; Arenius and De Clercq, 2005), and permit to circumvent some of the constraints faced by the entrepreneurs along the formation process (Johannisson, 1998; Ciabuschi et al, 2012). They facilitate the access to and effective use of resources and competences that are critical for the success of the new firm (Adler and Kwon, 2002; Greve and Salaff, 2003) and they also contribute to their credibility and legitimacy (Moensted, 2007).

Empirical research on the networks built by technological entrepreneurs and firms show that their configuration in terms of composition (i.e. actors) and structure (i.e. relationships) varies with the resource that is being accessed (Gilsing and Duysters, 2008; Sousa et al, 2011) and with the sector where firms operate (Plum and Hassink, 2011). It has namely shown that the type of relationships established by new technology-intensive firms will be largely determined by the nature of the knowledge being exploited and by the mode of industrial organisation of the sector/industry where the resulting technologies products are being introduced (Salavisa et al, 2012).

\footnotetext{
${ }^{2}$ New renewable electricity sources can be divided in: non carbon-based (wind, solar photovoltaic, small hydro, wave and tidal); and alternative carbon-based (biogas; biomass; landfill gas) (Darmstadter, 2003).
} 
Thus, it is to be expected that new research-based firms exploiting renewable energy technologies, like other technology-intensive starts-ups, will establish relations with a variety of actors to access resources and competences and to achieve legitimacy. But it is also to be expected that the nature of these relationships will be influenced by two types of factors: a) the nature and stage of development of their technology - that configure the technological environment where they operate; b) the characteristics of the energy / electricity production sector and also the particular features of the specific industrial segments they will address - that configure the business environment where they compete.

Research-based companies build their competitiveness on the ability to develop and constantly update their knowledge base (Yli-Renko et al, 2001). Thus, access to new knowledge is vital and relationships with universities and other research organisations are instrumental, not only to develop the first technologies but also to maintain the competitive edge through time (McMillan et al, 2000; Witt and Zellner, 2007). In the particular case of research-based spin-offs, research conducted in universities is usually the source of the technological opportunity and the new firms tend to maintain close relationships with their parent organizations, in particular at the early stages (Mustar et al, 2006). Besides being the main source of external knowledge, universities and research centres (in particular the parent organisation) can also provide other resources, namely facilities, human resources and credibility (Landry et al, 2006). More application-oriented research organisations or teams can also contribute to the definition of the business opportunity and/or be sources of industrial contacts.

However, the transformation of a technological opportunity into a marketable technology, product or service and its commercialisation, requires the combination of a variety of technological and nontechnological resources and competences (Autio, 1997; Teece, 1986). This process can raise particular difficulties to research-based spin-offs, since entrepreneurs will tend to have scientific backgrounds and thus lack managerial competences and business experience and also to have limited business networks (Ensley and Hmieleski, 2005). Thus the new firm will often need to obtain externally both the actual resources and information and advice about their sources and modes of deployment. Key resources include capital, production-related assets, market related assets, managerial competences and business intelligence, knowledge about intellectual property and regulatory processes (Mustar et al, 2006; Vohora et al, 2004). Entrepreneurially oriented research organisations may equally offer their start-ups early support at some of these levels: e.g. business training, seed-capital or access to sources of funding or incubation infrastructures (Clarysse et al, 2005). But firms will need to establish relationships with a variety of non-academic organisations, namely other firms - often large established companies - financial institutions, public and private agencies 
The access to potential partners and the establishment of a relationship with them can be complex for a new firm without a previous record, because the partner will have difficulties to assess the quality of the firm and its technologies (Choi and Shepherd, 2005). In these circumstances the personal network of the entrepreneurs can be an important asset, since endorsement by prestigious individuals/organisations may enable firms to overcome the early resistance towards unproven technologies, persuading established companies to invest in their development and commercialisation (Shane and Stuart, 2002). Technological relationships with reputed scientific partners as well as the presence of venture capital also signal quality, with similar effects (Luo et al, 2009; Shane and Cable, 2002). This type of credibility enhancement can be particularly important for technological entrepreneurs, since their personal networks may not encompass relevant contacts outside the scientific community (Elfring and Hulsink, 2003).

In order to understand the modes assumed by these relationships and the roles they play in the case of firms in the renewable energy sector we will subsequently discuss the nature of the environment where they are operating.

\section{The technological and business environment in the energy sector(s)}

New firms developing renewable energy technologies (RET) that have an application in the process of electricity generation and/or distribution are entering a sector that is both highly complex and undergoing profound changes. The sector is responsible for the production and supply of a basic resource - electricity - whose availability is critical for the functioning of the economy and the society at large. It is one of the largest sectors in the economy, encompassing a wide range of activities associated with the production, transmission and distribution of electricity, which tend to be highly centralised, given the infrastructural nature of the system. Until recently the sector was dominated by relatively mature technologies, characterised by strong economies of scale and was controlled by large national utility operators (frequently under public monopoly) and by large equipment manufacturers (often multinational companies) (Jacobsson and Bergek, 2004).

The sector has been experiencing profound changes, driven by the liberalisation of energy markets (that took place in most European countries) and by pressures for cleaner energy production that led to the introduction of measures for $\mathrm{CO} 2$ reduction and policies promoting the introduction of renewable energy sources (RES) (Jager-Waldau et al, 2011; Verbong and Geels, 2007). The evolution of the sector and the impact of these changes in the sectoral regime have been addressed by the literature, namely by the two main streams of the "regime transition" literature: the literature on sociotechnical transitions that proposes a multilevel perspective on regime transition (e.g. Geels, 2002; Geels and Schott, 2007; Verbong and Geels, 2010; Foxon et al, 2010); and the technology innovation 
systems literature that proposes a system functions approach (e.g. Hekkert et al, 2007; Jacobsson and Bergek, 2004; Hekkert and Negro, 2009). This literature have mainly addressed the processes taking place in the energy / electricity generation sector at a structural and functional level, but less attention has been put on the micro-level, more specifically at the level of specific firms' activities and strategies (Makard and Truffer, 2008; Kishna et al, 2011; Wustenhagen and Wuebker, 2011), which are the focus of our analysis. Nevertheless it has provided important insights regarding the nature and dynamics of the energy and/or electricity sector and the systemic mechanisms underlying its transition to a sustainable regime, associated with the introduction of RES. These are relevant for an understanding of the technological and business environment faced by new technology-intensive entrants and the type of strategic options open to them.

According to this literature, the changes underway introduced some destabilisation in the prevailing regime (Geels, 2002), leading to alterations in the sectoral knowledge base and in the industrial structure. The liberalisation of the energy sector brought about the extinction of public monopolies, with transmission of ownership and management to private companies operating in a competitive market. It also forced the separation between energy production, transmission, distribution and commercialisation, which made market entry comparatively easier, at least in some segments (Verbong and Geels, 2010).

In parallel, the creation of a growing space for renewable energies, drove a renewal of the industry knowledge base, creating opportunities for firms that develop and/or exploit new technologies, targeting the energy production process, or system-level problems associated with the introduction of renewable sources (Sine and David, 2003; Jacobsson et al, 2004; Brown et al, 2007). There was a fast increase in the level of $R \& D$ and in innovative activity in renewable energies, largely fuelled by government policies that sponsored research or provided incentives to the development or implementation of particular energy technologies (Ayari, 2012). This increase was namely reflected in the growth in patenting (Johnstone et al., 2010). The new technologies often started being developed in niches, given the high technological and market uncertainty associated with their exploitation (Schot and Geels, 2007; Raven, 2007). But some of them have reached a stage where wider commercial exploitation became viable (if not fully competitive with conventional sources), especially in countries that introduced policies promoting renewable energies. The distributed nature of some of the new energy sources also favoured new entry, which was further encouraged by a variety of incentives for production and use (Schoettl and Lehmann-Ortega, 2010). This challenged the dominant position of old utilities (Duncan, 2010) and led to some readjustments in the actor composition and balance of power (Verbong and Geels, 2010). 
However, despite these changes, the sector still retains its infrastructural and centralised nature and is still largely dominated by large companies (Hendry et al, 2007). Moreover, while production and commercialisation are open activities, distribution (grid management) usually remains under the control of the old utilities. In addition, in most countries production from renewable sources still provides only a minority of the electricity produced and the system is still largely fed by conventional sources - coal-fired, natural gas and in some cases nuclear plants - that, together with large scale hydropower plants (the older, most widely used and already mature renewable technology), still shape the electricity dominant regime (IEA, 2011a). This is a centralised regime that matches the competence and assets of large established players (Duncan, 2010).

The still limited penetration of renewable energies is largely related to production cost differentials and grid integration problems (Jacobsson and Bergek, 2004; Verbong and Geels, 2010; IPCC, 2011). In fact, with some exceptions (e.g. wind production is some locations) energy production from new renewable sources still did not reach cost parity with that originating from fossil fuel sources. Thus, the renewable business is still largely dependent on government policies, which may change, associated with political cycles. Consequently, its expansion is affected by the capacity of its promoters - companies or trade associations, research organisations, social movements - to influence the decisions of government and other key actors, which introduces some particularities in the institutional environment. On the other hand, the introduction of renewable sources raised a number of grid level problems associated with the decentralised and often intermittent nature of these sources, which create difficulties in guaranteeing security and reliability of production and distribution. Thus both technological and organisational innovations are still necessary for the wider diffusion of these technologies (Foxon et al, 2010).

\section{The position of incumbents and conditions for new entry}

\subsection{Incumbents behaviour in the electricity production sector}

As a result of the processes described above, the renewable electricity production and distribution sub-sector is currently characterised by fast technological change and, simultaneously, by an industrial structure where large established firms occupy dominant positions, at least in the renewable segments that are closer to maturity. However, the renewable energy field is far from being homogeneous. If we consider exclusively the new non-carbon based renewable sources - wind, solar and ocean ${ }^{3}$ - it is possible to observe great differences between technologies in terms of maturity and

\footnotetext{
${ }^{3}$ Hydropower is also a renewable non-carbon electrical energy source and it is currently responsible the highest proportion of renewable energy production. It has been used for several decades in parallel to fossil fuel alternatives, it is based on mature technologies and its large scale deployment is currently stabilised (at least in Europe). Although new small hydro technologies are registering some interest, they are not a target of research-based spin-offs, so were not included in this research
} 
level of market diffusion and therefore in terms of the actual structure of the respective "industrial segments” (Jäger-Waldau et al, 2011; IPCC, 2011). This have implications for technology intensive firms willing to enter the energy business, since it influences the nature of opportunities that are created and the conditions in which these can be exploited. In particular it influences the attitude of the firms that occupy a dominant position in the industry - the incumbents - and other key actors (e.g. capital providers and policy makers) towards new entrants and their technologies.

Currently "incumbents" include two types of firms: old energy utilities or energy equipment manufacturers that were able to reconfigure their business, redeploying their assets and competences to enter the new field; and new players. The latter can be large firms that diversified from other sectors into the energy business, or (particularly in countries that pioneered the development of specific technologies) "de novo" entrants that profited from the favourable environment around renewable energies to grow on the basis of innovation and first mover advantages (Dewald and Truffer, 2011).

Established companies are often reluctant to get involved in the early exploitation of more immature technologies, given the high uncertainty associated with their development and the absence of internal competences in the new fields (Levinthal, 1997; Walsh et al, 2002). Thus, incumbents repositioning themselves in the renewable energy field or diversifying from other sectors are more likely to invest in more mature technologies, preferably those that enable large scale energy projects and are closer to existing competences and competitive advantages ${ }^{4}$ (Hockerts and Wustenhagen, 2010; Duncan, 2010). Among non-carbon based sources, wind conversion technologies have these characteristics and this can explain its wider diffusion and also the increasingly dominant position of large firms in their exploitation (Kaldllis and Zafirakis, 2011) . First and second generation solar PV technologies may, in some contexts, be exploited in a similar fashion, despite the greater relevance assumed by distributed systems (whose logics departs considerably from the dominant centralised regime) and the much less stabilised character of the technology, where new generations of competitive designs continue to emerge, giving rise to a more turbulent industrial environment (Schoettl and LehmannOrtega, 2010).

The positioning of powerful companies in more stabilised renewable segments, with larger scale production, has dislodged entrepreneurs from the core activities and raised entry barriers. But even in

\footnotetext{
${ }^{4}$ Although these new entrants can be categorized as "entrepreneurs" according to the technological innovation systems framework (Hekkerts and Negro, 2009), it can be argued that the nature of their competitive advantage locates them closer to old incumbents in a terms of business model preferences.

${ }^{5}$ The maturity of wind as source of electricity production is reflected in the fact that some authors argue that it is already possible to identify a dominant wind regime within the renewable sector. Smith et al. (2005: 1493) identify a "embryonic regime dominated by three-bladed, horizontal axis megawatt-scale wind turbines operating in grid-connected clusters and supported through public policy".
} 
these fields there is still a variety of complex problems that require extensive technological developments. These include problems associated with the operation of the actual technologies (efficiency, costs, reliability) and system-level problems that emerged due to their distributed and intermittent nature. This creates opportunities for technology-intensive specialised suppliers that offer advanced solutions for these critical problems.

On the other hand, the still relatively unsatisfactory performance in terms of energy yield, costs and security of supply opens some space for the emergence of alternative designs (e.g. high altitude wind or third generation PV cells) which are often being developed and tested by new firms. In these areas we observe a variety competitive technologies being developed by different firms, often still at an experimental stage. The same happens in the case of emerging renewable sources that have not yet reached a commercial stage, such as those related with ocean energy conversion. The opportunities created by new technologies that depart substantially from the established knowledge base tend to be identified and exploited by new firms that originate from outside the industry (Winter, 1984). Research-based spin-offs are one particular case of "outsiders" that tend to materialise when the main source of technological opportunity are scientific advances (Klevorick et al, 1995). These firms tend to target fields or industries that base their competitiveness on the quick paced production and exploitation of advanced knowledge (Conceição et al, 2012). Therefore, new RET - in particular those that are still experiencing fast technological change - can offer good opportunities for their emergence.

Incumbents vary in their attitude to these less mature, emerging technologies (Hockerts and Wustenhagen, 2010). Among those originating from the energy field, ex-utilities are described as tending to be more conservative, and equipments manufacturers as showing a more proactive attitude, given their greater innovative orientation (Teppo and Wustenhagen, 2009). The positioning of the new players depends very much on their origin and goals and on the nature of the segment they target. But the growing international competition in the energy area has quickened the technological pace and increased the need to invest in innovation to maintain competitiveness, thus putting greater pressure on incumbents to look for new technologies or getting involved in alternative technological paths (Hekkert and Negro, 2009). Some of these may lead to substantial changes in the actual infrastructure and/or require an extensive renewal of the knowledge base, which can threaten incumbent assets and position. Thus incumbents may wish to keep an eye on the new developments, in order to follow-up (or even influence) their evolution and/or to guarantee an early position, once a dominant design starts to emerge (Dyerson and Pilkington, 2005; Sine and David, 2003). But they usually prefer to achieve this through collaborations that reduce the risks and costs involved. 
Thus, at least some incumbents (both old and new players) may be interested in developments that take place in less stabilised segments where technological development is faster, or even in fields that are still emergent. The interest in the new technologies developed by external actors may assume different forms, from simple technological watch, to participation in research activities (often coordinated by research organisations), to greater involvement with the firms that are developing and testing the new technologies. The latter can involve funding of entrepreneurial activities (including through corporate VC funds), participation in demonstration projects to test and/or validate the technology; alliances with firms developing technologies perceived to have future potential, or answering to actual needs of the company, but where it prefers to share the early risks and/or to avoid developing internal competences (Hockerts and Wüstenhagen, 2010; Dyerson and Pilkington, 2005). The presence and interest of large incumbents can be important for the development of the niches where these new technologies are exploited, since they convey resources and legitimacy and can make them attractive to other key actors, such as capital providers (Schot and Geels, 2007).

\subsection{Conditions for entry of small research-based start-ups}

The combination of strong incumbent power and fast technological development creates a particular environment for new firms introducing new technologies. The conditions faced by entrants in this type of environment and the strategic opportunities open to them have been addressed by the literature on the strategic management of technology (Teece, 1986; Arora et al, 2012). In particular, previous research has shown that when large incumbents control a number of key complementary assets, small technology-intensive start-ups may benefit from adopting “cooperative strategies” (Gans and Stern, 2003), entering in a variety of relationships with the established companies (Rothaermel, 2001). Indeed, in some sectors incumbents have developed a deliberate strategy of encouraging the external development of new or complementary technologies (Gawer and Cusumano, 2008; Orsenigo et al, 2001). But the types of relationships established and the actual positioning of the start-up relatively to incumbents will depend on a variety of factors. These include: the nature of the technology being developed, its distance from the incumbents knowledge base and its pertinence to the incumbents' competitiveness; the start-up capacity to protect the technology from appropriation; the actual relevance of the complementary assets possessed by the incumbents to the start-up, as well as start-up decisions on the position it wishes to occupy in the value chain (Teece, 1986: Conceição et al, 2012; Gans and Stern, 2003; Aggarwal and Hsu, 2009; Arora et al, 2001).

The capacity to protect the technology and the conditions of access to key complementary assets are basic elements in the start-up strategic decisions. "Complementary assets" is a generic label to a set of physical assets or knowledge and skills that are necessary to sell a complete product or service: e.g., manufacturing capacity, marketing, sales and distribution, regulatory knowledge (Teece, 1986). Start- 
ups can build (some of) them internally, can try to gain access to them, through market transactions or through alliances, or else can focus on technology development and licensing, avoiding an involvement in downstream activities (Arora et al., 2001). The decisions made at this level are strongly influenced by the nature of the assets, in particular those that are key to capture rents from the innovation. In fact, complementary assets can be generic and supplied by the market in competitive conditions, or co-specialised to the innovation (Teece, 1986). Co-specialised assets may not be readily available in the market, since their owners try to achieve control over them, and they may also be difficult to imitate, because they are built on the basis of a process of learning within the firm (Rothaermel and Hill, 2005). In these cases, access to these assets may require the establishment of a contractual relationship with the owner (Aggarwal and Hsu, 2009; Colombo et al, 2006; Shan et al, 1994). The problem is compound when such assets are owned by established, often more powerful firms, which may not be easily gained to such relationships, or may use their position to appropriate a substantial part of the rents from the innovation (Rothaermel and Hill, 2005).

In the limit, firms may choose to avoid engaging in the development of products/services and commercialise the technology instead, in particular when this technology is highly innovative and can be protected through patents (Conceição et al, 2011). However the literature also describes a variety of vertical alliances where the owners of the needed assets - to whom the new firms technologies/products are particularly interesting (Rothaermel, 2002) - assume part or all the manufacturing and/or commercialisation activities (Colombo et al, 2006; Stuart et al, 2007). These alliances can be mutually favourable, even if often characterised by a degree of power asymmetry (Shan et al, 1994).

Power asymmetry between partners increases the appropriability hazards, making firms vulnerable to the expropriation of their main (or even unique) asset (Teece, 1986). This type of risk may deter firms from establishing some types of alliances, unless the technology benefits from strong IP protection. Thus, the capacity to protect the technology is critical for start-ups whose competitiveness is based on the technology being introduced (Conceição et al, 2012). Formal appropriation mechanisms like patents are often the only effective means of protection for small firms, being particularly important for small technology suppliers (Arora and Merges, 2004). In the case of research-based spin-offs exploiting technologies developed in research organisations, this type of protection is often present. This is because new scientific knowledge is, in principle, more patentable and also because research organisations are putting growing emphasis on patenting (Clarysse et al, 2005). These patents are often transferred or licensed to the new firm, granting it protection from start-up and also having a quality endorsement function (Luo et al, 2009). 


\subsection{Start-up strategies in conditions of incumbent dominant position}

In their discussion of the commercialisation strategies open to new technology-based entrants Gans and Stern (2003) argue that the characteristics of the "commercialisation environment" constrain the choices to be made by the entrepreneurs. They define "commercialisation environment" along two dimensions - the extent to which innovation by the start-up precludes the incumbent's development and the relevance of incumbent complementary assets to the start-up innovation - and devise a typology of environments and associated strategies that result from their intersection. This concept is relevant for our analysis, since it addresses the type of conditions that may influence the attitude of incumbents towards the advanced technologies being developed by the new firms and the nature of the relationships that are likley to be established between both.

The specific environment labelled by the authors as "ideas factories" configures a set of conditions that is likely to emerge in the case of RET. In this case, invention by the start-up precludes effective development by more established firms, because the start-up ability to protect the technology makes its appropriation difficult; but established firms control the complementary assets required for its commercialization. This type of environment is conducive to a "cooperation strategy" which encompasses a range of possibilities from the licensing of the intellectual property, to the establishment of a variety of strategic alliances to, in the limit, the acquisition of the start-up. From the standpoint of the incumbent the relationship with a number of innovative start-up partners offers a fertile source of new ideas (technologies or products) in new fields where it has limited competences and/or where uncertainty is still too high and thus experimentation with a variety of competitive technologies/paths is still required (Raven, 2007). Thus, an awareness of these technologies/paths and/or the ability to gain quick access to their outcomes is perceived by incumbents as relevant for securing their market position and they may consider cooperation with start-ups as beneficial.

A cooperation strategy is also possible in an environment where appropriability problems exist (i.e. the capacity to protect the technology is lower) but where some incumbents may perceive advantages in developing a reputation of fairness in their dealings with start-ups that are developing relevant technologies, thus deflecting the threat of appropriation. This posture can offer particular benefits for the incumbents that adopt it, since it may enable them to gain an innovative advantage upon competitors. This environment, labelled by Gans and Stern (2003) as "reputation-based ideas trading” - is equally conducive to alliances with (some) incumbents.

Alliances with incumbents have benefits for the start-up, enabling it to access markets and supply chains; and providing capital for technology development and sometimes conditions for the realworld testing or demonstration of its technologies/products. Thus, they reduce the investment the 
start-up has to make on downstream assets (Arora et al, 2001) and also offer advantages in terms of legitimacy building. However they also entail risks that have been extensively discussed in the literature on alliances (Lerner and Merges 1998). Moreover, as Gans and Stern (2003) point out, these alliances tend to reinforce the basis for incumbents' advantage and thus their market power, in particular if the technologies that are being developed by the start-ups reinforce existing platforms.

However, Gans and Stern (2003) also argue that when incumbent complementary assets are less important and the technology can be protected from appropriation - the "greenfield competition" environment - the start-up may consider the choice between collaborating and competing. The ability to control the development of platforms and standards - and thus having some control over the subsequent development of the technology - is critical if the start-up decides to avoid cooperation and engage in product market competition. On the other hand, in these environments the new entrant has a stronger bargaining power relatively to potential partners and can define where and which conditions to cooperate.

Early pharmaceutical biotechnology stands-up as an extreme case in which start-ups located upstream in the value chain had to establish alliances with incumbents that controlled the downstream assets but did not dominate the new knowledge and were interested in gaining access to it (Orsenigo, 1989). It is equally exemplary of a situation in which alliances reinforced the incumbents' position, while the new entrants remained small technology suppliers or ended-up acquired. However, even in this sector the relationships between large incumbents and small new entrants evolved over time, as incumbents gained competences in the new knowledge; and as technologies with different characteristics were introduced that afforded new entrants a greater margin of manoeuvre in these alliances (Orsenigo et al, 2001), or enabled them to engage in different market strategies (Gottinger and Umali, 2011). Moreover, in other sectors, relationships between technology-intensive start-ups and large incumbents have also emerged, assuming a greater variety of forms (Colombo et al, 2006; Grimaldi and Torrisi, 2001). However, there is still limited knowledge about the relational behaviour of start-up firms willing to introduce new renewable technologies in the energy sector.

It is therefore relevant to understand the impact of the technological and business environment of the (renewable) electricity sector on the strategic options open to research-based firms introducing new technologies and on their relationships with the incumbent firms.

\subsection{Research-based spin-offs and the process of commercialisation of the new RET}

When addressing the strategies of research-based spin-offs in the commercialisation of RET we are confronted with a gap in the literature. In fact, as was recently pointed out by some authors, despite 
extensive body of research on the changes undergoing in the energy sector, there is still limited understanding of the strategies of individual firms (Mackard and Truffer, 2008). Previous research has provided insights about the changes that have occurred at a system macro-level and about the roles/functions that are played along these processes (Verbong and Geels, 2010; Hekkert and Negro, 2009), but there is still limited understanding of micro-level aspects, namely the strategies of individual firms and their relationship with the system (Wustenhagen and Wuebker, 2010; Kishna et al, 2011; Musiolik and Markard, 2011; Hockerts and Wustenhagen, 2010).

So far, entrepreneurs have been presented as playing an important role in the transition process, bringing in both new technologies and new attitudes and thus contributing to set-off change (Hekkert et al, 2007). Moreover, they are presented as interacting with other actors in order to gain them to their new ideas and to build support to their development and introduction (Raven, 2007). However, there is still limited knowledge on how research-intensive firms act to develop and introduce the new renewable technologies, on how they interact with other elements of the system to access and deploy the variety of resources necessary for the innovative process and, more generally, on the impact of the conditions found in this particular system upon firms' actual formation and behaviour.

To address this gap, this paper proposes an exploratory research at the micro-level, based on an indepth analysis of the relational behaviour of research-based spin-offs in the process of development and early commercialisation of their technologies. The research is expected to provide some preliminary insights into the following questions:

- Which types of relationships are established by new firms in the start-up and early development stages?

- What types of actors play a relevant role and which are these roles?

- In particular, which is the relationship between the new firms and large established companies (that often occupy dominant positions in the sectors where they are entering) in the process of commercialisation of their technologies? That is:

o which is the attitude of the incumbents relatively to the new firm technologies/ activities?

o which is the strategy adopted by the new firm relatively to incumbents?

- Are there differences between energy fields and/or between technologies in different stages of development regarding the conduction of this process? And at which levels do these differences emerge?

In order to guide this research we draw on three main streams of literature. First of all we draw on the literature on technological entrepreneurship to identify the type of the resources that research based spin-offs are likley to search through external relationships and the type of partners they are likely to mobilise for that purpose. We focus on three main types of resources - knowledge, complementary assets and legitimacy (Sousa et al, 2012) - and drawing on the methodological contributions of the 
literature on social networks we trace the relationships established by the new firms in order to obtain them and investigate the nature and contents of these relationships. Our objective is to identify the resources that emerge as critical for to energy start-ups and the functions played by different types of actors in their access and deployment, during the creation and early development of the new firm.

Secondly we draw on the literature on strategic management of the technology to investigate in greater detail the relational strategies adopted by the start-ups in process of commercialisation of their renewable energy technologies, as well as the attitudes adopted by established companies that often have a dominant position in the sectors they are entering. Building on Gans and Stern (2003) concept of "commercialisation environment" we define an analytical framework, based on two main dimensions: the need for and relevance of co-specialised complementary assets, possessed by incumbents for capturing the value of the technology; the positioning of incumbents relatively to the technology exploited by the new firm, i.e. whether the technology is relevant for them and whether the new firm can preclude its appropriation. In order to characterise more precisely the environment(s) that prevail in the energy sector, we draw on the transition literature to understand the structure and dynamics of the sector and the impacts of the changes underway. This framework enables us to assess the position of the new firm relatively to incumbents and to understand the rationale for the decisions made regarding the nature of the relationships established (or not) with them. It also enables us to explore the attitudes of the incumbents with whom the new firm ends up establishing a relationship, which is further supported on literature on the attitude of incumbents towards technologies that threaten established positions.

Thirdly we draw on the empirical literature addressing the emergence and development of the renewable energy sector that point to substantial differences between RETs in terms of technological maturity and market penetration. This literature supports the notion that different energy fields - and within them different energy segments based on specific technologies - may generate different conditions for new entrants (i.e. different competitive environments) and thus are likley to influence the commercialisation strategies adopted by the respective firms. This notion of variety of behaviour across energy fields/segments is thus regarded as a key dimension in the analysis. Its implications are investigated through the comparison of cases differently positioned in terms of field/technology.

\section{Empirical analysis}

The empirical analysis uses a case study approach to gain an in-depth understanding of the process of firm creation and early development, focusing on the role played by relationships with different types of actors in that process. The research addresses the case of research-based start-ups introducing noncarbon based RET in Portugal. This empirical setting appears to be relevant for our analysis since 
Portugal has been investing strongly in the development and deployment of RET, being currently one of the European countries with a higher penetration of renewable energy sources in electricity production. These efforts created the conditions for the emergence of new companies that are exploiting the results of academic research in the energy market, which are the object of this analysis.

Before presenting the case studies, we will provide a brief overview of the empirical setting. This includes a short description of the Portuguese industrial and institutional environment in the energy sector, with particular emphasis on the specific segments addressed in this research, including an assessment of the nature of the key players. It also includes brief description of the emergence and population of university spin-offs operating in this field. We will then present the methodology used in the empirical research.

\subsection{General overview of renewable energy in Portugal}

In the last decade, Portugal made a strong investment in the development of the renewable energy area. A number of ambitious targets regarding energy generation from renewable sources were put forward from mid 2000s onwards, following recommendations from the European Union; and policies were introduced to support their attainment. According to the most recent strategic document - the National Strategy for Energy (ENE 2020) - 31\% of the final energy consumption is expected to derive from renewable sources in 2020. In addition the government set increasingly ambitious targets for the weight of these sources in electricity production, which is currently expected to reach $60 \%$ in 2020 (MEID, 2010).

A varied set of policy incentives were introduced for the promotion of renewable energies in electricity production. The main mechanisms is a feed-in tariff, that is, a regulatory policy that that sets a price at which power producers can sell renewably generated electricity into the grid, that is guaranteed over a certain period of time. All technologies used in the generation of electricity from renewable sources are eligible, although the amount of payment depends on the source of energy and on the technology used, as well as on system's output and capacity. Energy originating from RES has priority of access into the grid. Besides the feed-in tariff, Portugal also resorts to other mechanisms such as fiscal incentives, public financing (trough public investment or grants) and public competitive bidding (REN21, 2011). Among these can be mentioned a very favourable regime for grid-connected micro-generation. It is also worth mentioning the setting-up of an Innovation Fund, based on the amounts obtained from the awarding of licenses to construct and operate energy power plants, whose goal was to support the development of new energy technologies. Taken globally, the several energy policy documents launched by the government, in particular during the second half of the 2000s, presented the development of competences and industrial activities in renewable energies as a driver 
of the country's progress (namely profiting from a favorable endowment in renewable sources) and offered a "vision" of Portugal as an exemplary case of their use, which was largely diffused by the media, creating a certain hype around the field.

As a result to this effort the degree of penetration of renewable energies registered a fast growth (Table 1). In 2010 the contribution of renewable sources to the country's gross electricity consumption was about 50\%. This amounted to an installed capacity of $9414 \mathrm{MW}$, of which about $50 \%$ corresponded to hydropower (where the country has a longstanding tradition) and another $40 \%$ to wind. Other sources had a smaller contribution: biomass (including co-firing) amounted to $5 \%$ and solar PV to only 1\%. More recent data (October 2011) shows an increase capacity to 10299MW, mainly deriving from wind, solar and hydro. The total installed capacity almost doubled between 2003 and 2010, wind power being the main responsible for this growth: it increased from 253 to 4283 in October 2011. Solar PV registered the highest growth in the period under analysis, due to the installation of two large power plants, but its contribution remains small.

Table 1 - Evolution of installed capacity by renewable energy source (MW)

\begin{tabular}{|l|rrrrrrrr|c|c|}
\hline & $\mathbf{2 0 0 3}$ & $\mathbf{2 0 0 4}$ & $\mathbf{2 0 0 5}$ & $\mathbf{2 0 0 6}$ & $\mathbf{2 0 0 7}$ & $\mathbf{2 0 0 8}$ & $\mathbf{2 0 0 9}$ & $\mathbf{2 0 1 0}$ & Oct 2011 & $\begin{array}{c}\text { AARG } \\
(2003-10)\end{array}$ \\
\hline Hydropower & 4292 & 4561 & 4752 & 4784 & 4787 & 4792 & 4821 & 4837 & 5268 & $1.7 \%$ \\
Wind & 253 & 537 & 1047 & 1681 & 2446 & 3012 & 3507 & 3865 & $\mathbf{4 2 8 3}$ & $47.6 \%$ \\
Biomass (co-firing) & 352 & 357 & 357 & 357 & 357 & 357 & 359 & 360 & 360 & $0.3 \%$ \\
Biomass (other) & 8 & 12 & 12 & 24 & 24 & 24 & 101 & 106 & 106 & $44.6 \%$ \\
Waste & 88 & 88 & 88 & 88 & 88 & 88 & 88 & 88 & 90 & $0.0 \%$ \\
Biogas & 1 & 7 & 8.2 & 8.2 & 12.4 & 12.4 & 20 & 28 & 38.9 & $61.0 \%$ \\
Solar PV & 2.1 & 2.7 & 2.9 & 3.4 & 14.5 & 58.5 & 104.1 & 125.8 & $\mathbf{1 4 9}$ & $79.4 \%$ \\
Wave/tidal & 0 & 0 & 0 & 0 & 0 & 4.2 & 4.2 & 4.2 & $\mathbf{4 . 2}$ & - \\
\hline Total & 4996 & 5565 & 6267 & 6946 & 7729 & 8348 & 9004 & 9414 & 10299.1 & $9.5 \%$ \\
\hline
\end{tabular}

Source: Department of Energy and Geology/ Ministry of Economy

Comparing Portugal with other European countries, we observe that in 2009 the country ranked third among the EU15 countries regarding the proportion of renewable sources in electricity production and was fourth in the ranking of countries with the highest penetration of wind power in its electricity production mix (Table 2). 
Table 2 - Renewable sources in electiricity production: comparison between EU15 countries

\begin{tabular}{|c|c|c|c|c|c|c|c|}
\hline & \multicolumn{2}{|c|}{ \% RES } & \multicolumn{4}{|c|}{ Weight (\%) in 2009} & \multirow{2}{*}{$\begin{array}{r}\text { \%RES } \\
1999-2009 \\
\end{array}$} \\
\hline & 1999 & 2009 & Hydro & Wind & Bio & Others & \\
\hline Austria & 74,9 & 67,2 & 83,4 & 5,2 & 11,3 & 0,0 & 6,8 \\
\hline Sweden & 50,8 & 56,9 & 82,7 & 3,2 & 14,1 & 0,0 & 5,0 \\
\hline Portugal & 21,4 & 35,9 & 46,5 & 39,7 & 9,6 & 4,2 & 115,5 \\
\hline Denmark & 13,3 & 27,3 & 0,2 & 67,5 & 32,3 & 0,0 & 105,0 \\
\hline Finland & 26,7 & 25,9 & 58,6 & 1,3 & 40,1 & 0,0 & 0,7 \\
\hline Spain & 14,3 & 25,3 & 36,2 & 50,6 & 4,7 & 8,5 & 136,2 \\
\hline Italy & 19,0 & 19,7 & 72,0 & 9,2 & 9,6 & 9,2 & 13,0 \\
\hline Germany & 6,7 & 16,3 & 18,3 & 39,7 & 35,5 & 6,5 & 156,0 \\
\hline Ireland & 6,1 & 14,2 & 22,3 & 73,2 & 4,5 & 0,0 & 195,2 \\
\hline France & 17,5 & 13,4 & 82,0 & 11,2 & 5,9 & 0,9 & $-14,1$ \\
\hline Greece & 10,4 & 11,5 & 68,6 & 28,7 & 2,6 & 0,1 & 33,3 \\
\hline Netherlands & 4,6 & 9,3 & 0,9 & 42,3 & 56,4 & 0,4 & 122,5 \\
\hline UK & 3,4 & 6,5 & 21,4 & 34,7 & 43,8 & 0,1 & 87,6 \\
\hline Belgium & 3,2 & 5,8 & 8,0 & 19,1 & 69,7 & 3,2 & 90,3 \\
\hline Luxembourg & 16,6 & 3,5 & 36,3 & 25,0 & 30,9 & 7,8 & $-68,6$ \\
\hline Total UE15 & 15,2 & 19,1 & 53,7 & 23,9 & 18,6 & 3,8 & 36,5 \\
\hline
\end{tabular}

Source: Department of Energy and Geology/ Ministry of Economy

Despite these remarkable results, the continuity of these efforts may be partially threatened by the current economic and financial crisis ${ }^{6}$. In fact the energy policy is currently under revision and the government announced the intention to modify the support scheme for renewable energy (DGEE, 2012). While this includes a necessary adjustment of tariffs for technologies whose costs have substantially decreased, some other changes can considerably slow down the development and implementation of RET. As was shown by the experience of other countries, this can have a serious long term impact on the development of the renewable energy sector (Negro and Hekkert, 2010).

\subsection{The creation of energy spin-offs}

The policy efforts towards the development and dissemination of RET and the expansion of the renewable electricity production sector created a favourable environment for the creation of new firms exploiting advanced energy or energy-related technologies. This is the case of firms commercialising research or technologies originating from the university - research spin-offs.

The creation of university spin-offs in this field is a recent phenomenon, which basically started in the 2000s, registering a substantial increase in the last 5 years. This increase can be explained by the growing focus put by some universities on energy or energy-related research, as well as by the

\footnotetext{
${ }^{6}$ In early 2011 (May) the country ranked $10^{\text {th }}$ in the Ernst \& Young "Renewable Attractiveness Index". However its position had fallen to $21^{\text {st }}$ one year later (February 2012), as a result of the changes announced (or expected) for the sector, in the aftermath of the international intervention. [http://www.ey.com/GL/en/Industries/Oil--Gas/Oil_Gas_Renewable_Energy_ Attractiveness-Indices]
} 
emergence of new market opportunities, associated with the expansion of the sector. Additionally, the recent "hype" around the energy field led to the launch of a number of initiatives promoting the creation of "green businesses", some of them specifically targeting highly innovative ideas or university based ones. Among these can be highlighted an Innovation Ideas contest promoted by the energy utility that has supported the creation of a number of university spin-offs and that was, more recently, complemented with the creation of an incubator specifically targeting new energy start-ups. Firms also benefitted from a multiplication of generic mechanisms and incentives promoting technological entrepreneurship and spin-off creation (from public and/or private initiative) that took place during the last decade. Finally, we can also observe some recent interest of venture capital firms in a few promising energy spin-offs, although the number of companies that were able to secure financing is still very limited ${ }^{7}$.

In the absence of systematic information on new research-based firms introducing new RET, it was necessary to conduct a preliminary identification of existing firms and a subsequent collection of generic information on them. This task was based on published data, namely in university and incubator webpages, in the business press and in the webpages of industry associations, and on on-line information about winners of business ideas and entrepreneurship programmes. As a result of this exercise it was possible to identify 65 university spin-offs operating in the energy field by the end of 2011, including firms active in the renewable energies and in the energy efficiency areas (Figure 1).

Figure 1 - University spin-off creation in the energy area (renewable energies and energy efficiency)

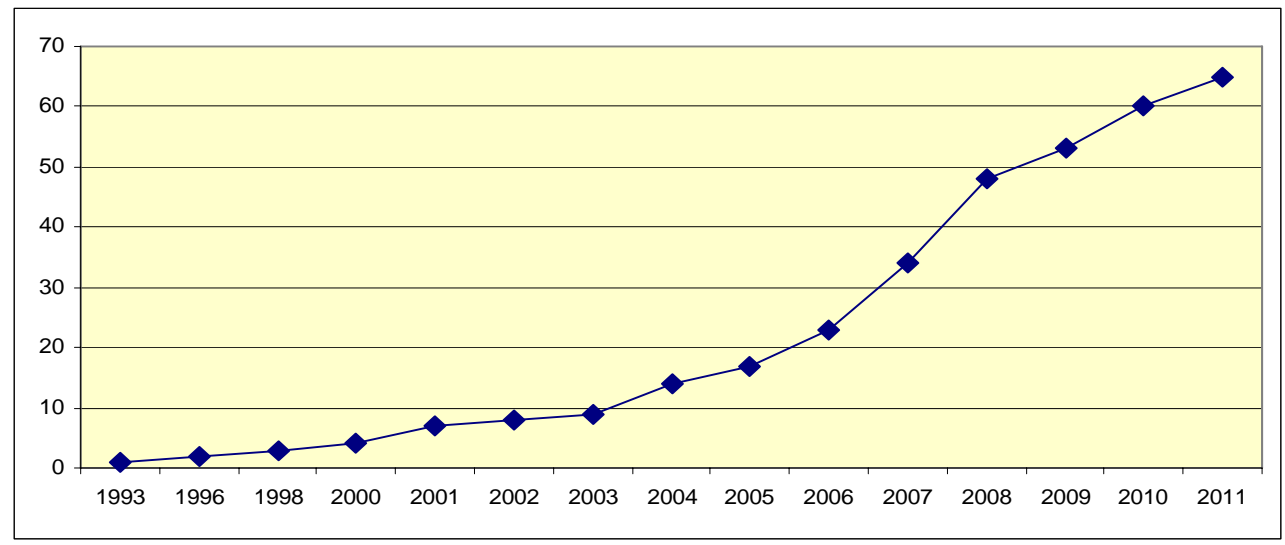

However, only a subset (38) can be described as research-based firms, whose creation drew on the development of new technologies. The remaining are mostly specialised service firms that use the competences of their founders to propose new energy solutions, based on existing technologies, to the residential or small scale commercial/industrial market. The majority offer integrated services that can

\footnotetext{
${ }^{7}$ An analysis of the portfolios of the most important Portuguese VC funds found that by 2011 they had invested in 10 energyrelated companies in different areas, of which 8 were university spin-offs.
} 
be generically classified in the energy efficiency field (21), while a smaller subset specialises in the installation of renewable energy systems (6).

In this paper we are interested in firms developing new technologies targeting the renewable energy production sector. This is the largest group (33 firms), since there are few firms developing own technologies in the energy efficiency area. Most technology developers target only one energy segment. Bioenergy, wind and solar are the main application areas. The bioenergy group is mainly composed of firms that develop innovative equipments and systems for the production of biogas. The emergence of this group of firms was associated with the development of research in biotechnology that took place in the late 1990s, thus slightly earlier than the current "energy trend", but a number of them ended-up identifying a market in the biomass or biogas production fields. Thus most firms in this group have a distinct origin and path. Since we are focusing on the non-carbon based renewable technologies, these firms will not be part of the current analysis. Thus we are left with 26 researchbased spin-offs that fall within the scope of this research.

Figure 2 - Research-based spin-offs by application field

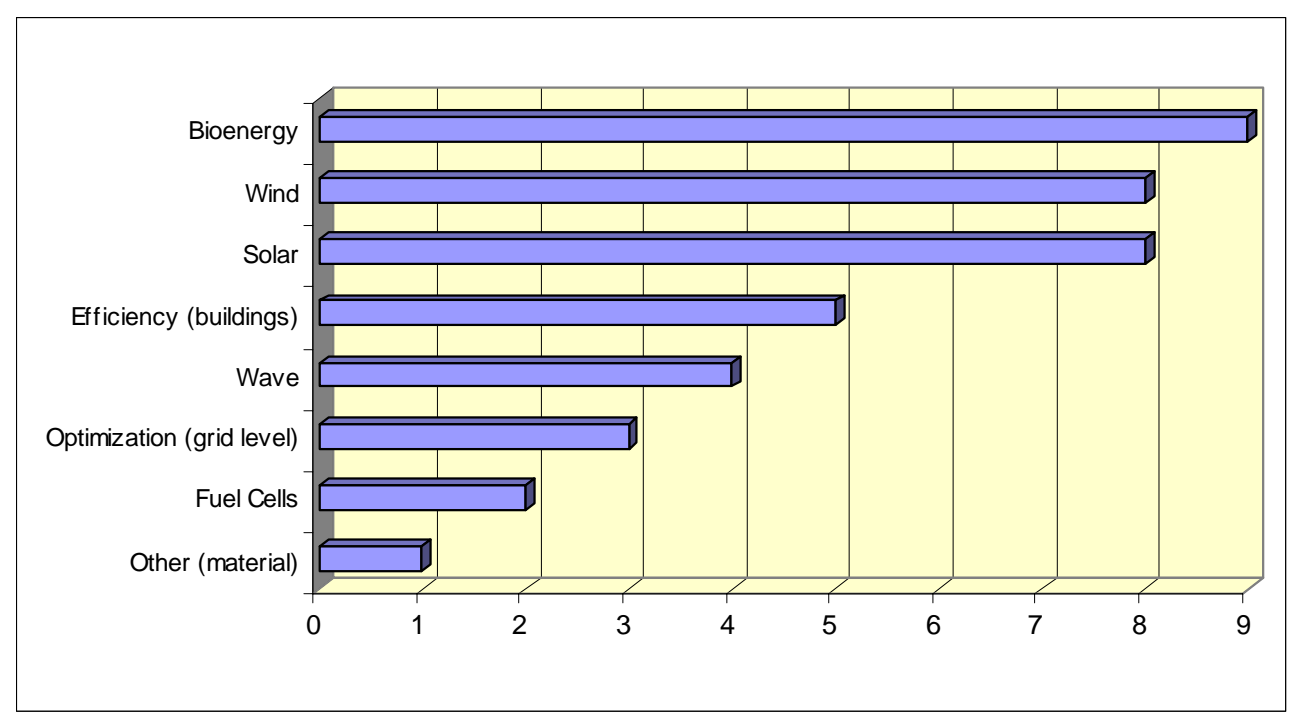

The group of firms operating in the wind field are mostly producers of intermediate technologies to the wind farming sector. This energy segment is dominated by large companies, mostly drawing on imported technologies. Thus wind spin-offs tend to be involved in the development of technologies to improve the productivity of electricity production from wind sources, e.g. new materials, monitoring and control instrumentation and systems, sophisticated weather assessment or forecast systems. But we still find a very small group experimenting new alternative wind technologies. 
On the contrary, in the solar field we can find several companies developing and selling solar systems, namely new generations of PV technologies. They are namely engaged in the development of new types of cells, or of building-integrated photovoltaic materials. On the contrary, in the solar field we find several companies developing solar systems, namely new generations of PV technologies: e.g. new types of cells, or building-integrated photovoltaic materials, but the majority in not yet in the market. In fact most solar spin-offs were created in the last 2 years, encouraged by the recent emergence of market for grid connected distributed solar systems.

Portugal has some research and experimental tradition in the wave energy field and thus, despite the very preliminary stage of development of wave technologies, we can find 4 spin-offs operating in this field developing and testing competing equipment and systems. The energy storage field is the less developed, we still find two firms in this field (one of them combining it with other activity), both with a strong $R \& D$ orientation, which are involved in the use of fuel cells for the storage of excess electricity derived from the intermittent nature of renewable sources. Finally, the need to solve the grid management problems associated renewable energy production is providing opportunities for entrepreneurs with competences in area such as modelling and data mining to offer solutions at grid level. Spin-offs are starting to emerge that provide methods, instruments and systems addressing different stages of the electricity distribution.

\subsection{Research methdology}

\subsubsection{Selection of cases}

The firms for the case studies were selected among the 26 research-based spin-offs exploiting non carbon-based renewable technologies with application in the electricity production sector. The selection of the cases was based on a number of criteria that were expected to provide a variety of situations regarding a number of key dimensions in our research: energy field, maturity of the technology, type of business and age.

The choice of "energy field" and "maturity of the technology" as criteria was based to our expectation that differences at these two levels produce variation in the behaviour of the new firm, as well as on the attitude of established companies relatively to the technologies being introduced. In addition, "type of business" was chosen because the decision on the business to pursue is expected to influence the need for certain resources (namely downstream complementary assets) and produce variation in the nature of relationships established. Finally, there were two main reasons behind the choice of "age”. On one hand, it was considered necessary to have firms created in different historical moments, 
in order to account for the impact of the evolution registered in the various fields (in terms of research output, government policies and industry development). On the other hand, it was judged important to have firms in different stages of development. This permitted to have both firms already with some history which enabled us to consider their evolution; and firms going through the actual processes, which permitted to avoid the recollection bias that is inevitable when describing past events.

Thus the selection was conducted along the following dimensions:

1) Field of activity - cover the three main fields encompassed in the non-carbon renewable energy technologies: wind, solar, ocean.

2) Maturity of technology - include technologies in more or less mature stages of development, including, within a given field, more and less mature segments (e.g. on-shore wind vs. high altitude wind).

3) Type of business - include firms focused on intellectual property development and licensing (technology-oriented), firms developing and selling own products (product-oriented) and firms offering advanced services.

4) Age - include firms introducing the technology and firms already in the market, ideally including also firms introducing 2nd generations of technologies, when available.

\subsubsection{Data collection}

Data for the case studies were collected through detailed interviews with the founders, complemented with an extensive search for documentary information on the firms. The interviewees were asked to provide a brief history of the firm creation and then to give detailed information on the relationships established by the firm along the process of the development and market introduction of the technologies being exploited. The latter was supported by a semi-structured questionnaire already tested in other sectors for obtaining information about the composition and roles of entrepreneurs and firms networks (Salavisa and Fontes, 2012). The data collected encompassed three stages: the pre start-up; the start-up process; the early development of the firm. Data collection on relationships was centred on the resources (material and immaterial) and competences necessary for the identification and the exploitation of opportunities and on how they were obtained: which type of relationships and with whom (organizations or individuals), how they were established, how they evolved, which was their importance to the firm.

Based on the detailed information obtained, the analysis of the cases permitted to identify the actors that were relevant along the development and market introduction of the technologies exploited by the firms; the types of relationships established, the conditions in which they were formed; the nature of the resources obtained through them. 


\section{Case studies}

\subsection{Firms in the case studies}

The case studies are still underway. In a first stage five cases were conducted. They include firms operating in the following fields:

- Wind: wind plant management; high altitude wind; off-shore wind (combined with wave)

- Wave: wave engineering services and products (combined with offshore wind); wave conversion systems

- Solar: concentrated photovoltaic (CPV)

In terms of maturity of the technology these firms can be roughly located in a scale from emerging to more stabilised, as shown in Figure 2.

Figure 2 - Firms in case studies positioned along technology maturity continuum

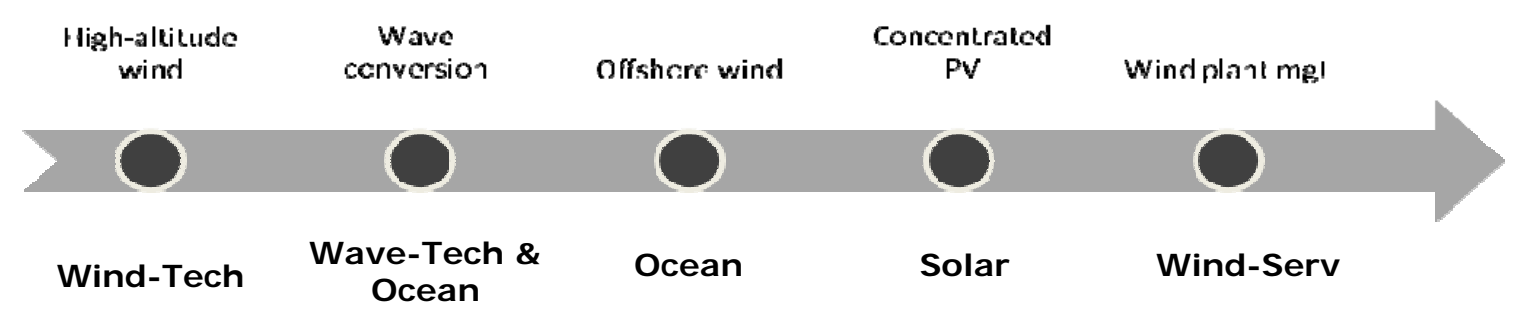

\section{Emerging}

Stabilised

The cases already conducted cover the selection criteria described in section 5.3.1 individually, but they still do not provide enough variety of situations to enable a combination between field, technology, types of business. Therefore the focus of the analysis will be on the implications of field /maturity of the technology for the firms' relational behaviour. Given the small number of cases the conclusions at this level are still preliminary and will require some additional cases for confirmation/refutation as well as greater substantiation.

The main characteristics of the firms studied are presented in Table 3 and their individual case stories are described subsequently. 
Table 3 - Firms in case studies

\begin{tabular}{|c|c|c|c|c|c|}
\hline Firm & WAVE-TECH & OCEAN & WIND-TECH & WIND-SERV & SOLAR PV \\
\hline Year creation & 2009 & 2005 & 2003 & 2004 & 2006 \\
\hline Field & $\begin{array}{l}\text { Wave energy } \\
\text { conversion }\end{array}$ & $\begin{array}{l}\text { Solutions in wave } \\
\text { energy conversion; } \\
\text { expanding to Off- } \\
\text { shore wind }\end{array}$ & $\begin{array}{l}\text { High altitude } \\
\text { Wind Energy } \\
\text { Conversion } \\
\text { (\& energy storage) }\end{array}$ & $\begin{array}{l}\text { Wind resource } \\
\text { assessment (on- } \\
\text { shore) }\end{array}$ & $\begin{array}{l}\text { Solar PV systems } \\
\text { (concentrated PV) }\end{array}$ \\
\hline Business & $\begin{array}{l}\text { Product } \\
\text { development }\end{array}$ & $\begin{array}{l}\text { Customised } \\
\text { development } \\
\text { (products); R\&D } \\
\text { and engineering } \\
\text { services }\end{array}$ & $\begin{array}{l}\text { IP development } \\
\text { and licensing }\end{array}$ & $\begin{array}{l}\text { Specialised services } \\
\text { for wind plant } \\
\text { optimization based } \\
\text { on own methods }\end{array}$ & $\begin{array}{l}\text { Product development } \\
\text { and sales; Integrated } \\
\text { services }\end{array}$ \\
\hline $\begin{array}{l}\text { Stage of } \\
\text { development }\end{array}$ & Prototype & $\begin{array}{l}\text { In the market with } \\
\text { products and } \\
\text { services for } \\
\text { experimental } \\
\text { installations }\end{array}$ & $\mathrm{R} \& \mathrm{D}$ & $\begin{array}{l}\text { In the market with } \\
\text { services }\end{array}$ & $\begin{array}{l}\text { In the market with } \\
2^{\text {nd }} \text { generation of } \\
\text { products }\end{array}$ \\
\hline Patents & $\mathrm{Y}$ & $\mathrm{Y}$ & $\mathrm{Y}$ & $\mathrm{N}$ & $\mathrm{Y}$ \\
\hline $\begin{array}{l}\text { Market } \\
\text { (expected) }\end{array}$ & $\begin{array}{l}\text { (Energy producers } \\
\text { \& distributors) }\end{array}$ & $\begin{array}{l}\text { Wave energy } \\
\text { companies; Off- } \\
\text { shore wind } \\
\text { companies }\end{array}$ & $\begin{array}{l}\text { Research } \\
\text { organizations } \\
\text { (energy producers } \\
\text { \& distributors) }\end{array}$ & Wind companies & $\begin{array}{l}\text { Micro-generation for } \\
\text { final consumers: } \\
\text { households, firms } \\
\text { (mini-generation) }\end{array}$ \\
\hline $\begin{array}{l}\text { International } \\
\text { market } \\
\text { (expected) }\end{array}$ & $\begin{array}{l}\text { (product sales \& } \\
\text { licensing) }\end{array}$ & $\begin{array}{l}\text { Contracts with wave } \\
\text { companies }\end{array}$ & R\&D contracts & $\begin{array}{l}\text { Direct consultancy } \\
\text { \& subsidiaries in } \\
\text { some markets }\end{array}$ & $\begin{array}{l}\text { Commercial } \\
\text { agreements or } \\
\text { licensing for } \\
\text { manufacturing }\end{array}$ \\
\hline Team & $\begin{array}{l}\text { Young university } \\
\text { students }\end{array}$ & $\begin{array}{l}\text { University } \\
\text { professors (senior) } \\
\text { \& industry } \\
\text { engineers }\end{array}$ & $\begin{array}{l}\text { Young researcher } \\
\text { in international } \\
\text { organisation }\end{array}$ & $\begin{array}{l}\text { Senior researchers in } \\
\text { industry oriented } \\
\text { organisation }\end{array}$ & $\begin{array}{l}\text { Young university } \\
\text { researchers } \\
\text { (international } \\
\text { background) }\end{array}$ \\
\hline Incubation & Utility laboratories & University & $\begin{array}{l}\text { International } \\
\text { agency }\end{array}$ & No & Technology park \\
\hline Incentives & $\begin{array}{l}\text { Prizes in Ideas } \\
\text { contests }\end{array}$ & $\begin{array}{l}\text { European and } \\
\text { National RDT } \\
\text { Programs }\end{array}$ & $\begin{array}{l}\text { European \& } \\
\text { National RDT } \\
\text { Programs }\end{array}$ & $\begin{array}{l}\text { National Innovation } \\
\text { Prog }\end{array}$ & $\begin{array}{l}\text { Prizes in Ideas } \\
\text { contests } \\
\text { National RDT \& } \\
\text { Innovation Prog. }\end{array}$ \\
\hline Capital & $\begin{array}{l}\text { Own }+ \text { prizes } \\
\text { (business angels) }\end{array}$ & Own + subsidies & Own + subsidies & Own & $\begin{array}{l}\text { Own }+ \text { prizes }+ \\
\text { subsidies }\end{array}$ \\
\hline
\end{tabular}

\subsection{Brief overview of industry segments of case studies}

Before presenting the cases we will provide a brief overview of the segments where the firms are located, to allow a better understanding of the conditions in which they operate, since the "renewable energy sector" is far from being homogeneous. There are substantial differences between RET in terms of knowledge base (which often rooted on different scientific and technological fields), stage of technological development and degree of market penetration. This is reflected in the industrial structures that can differ in terms of actor composition, competition conditions and growth potential. There also country specificities in the configurations that such structures may assume (Jäger-Waldau e tal, 2011; WAVEC, 2009; Kaldllis and Zafirakis, 2011; Carvalho et al, 2011; IEA, 2011b). 
Wind conversion is the most mature of the new RET. Onshore wind has the highest penetration, the technologies being now mainstream in many markets (as is the case of Portugal). In fact, the maturity of the technology has made it interesting for large scale application, even if its full deployment is still constrained by reliability and grid integration problems. In Portugal the characteristics of the technology and extensive government incentives have attracted large investors (including the old utility) that are now the dominant players. However, the implementation of wind systems was based on imported technology and therefore innovation is less likely to addresses core technologies, focusing on system organisation and operation. Opportunities for new technology- intensive companies emerge in the development of advanced technologies that address efficiency and management problems. One of the firms studied offers services in that area.

However the wind sector also presents some developing or emerging segments that are expected to overcome its current shortcomings (e.g. intermittence, environmental impacts). One is offshore wind that offers greater energy potential (since wind speeds are higher at sea), but is more complex in technology terms, resulting in higher energy costs. Several technological solutions are under experimental development in a field dominated by large international firms. One of the firms in the case studies provides specialised engineering services in the less developed field of deep-water offshore. Another is high altitude wind. This is a very recent field and both the knowledge about wind behaviour at high altitude and the technologies for capturing power from it are still in a very incipient stage. However there is a number of companies worldwide testing different types of mechanisms, with small scale prototypes being developed. This is the case of one of the companies in our cases studies.

Solar photovoltaics (PV) is a rapidly developing technology, that has recently achieved some market penetration, but is still far from having reached cost competitiveness with conventional sources. In spite of the higher costs and uncertainty related with the presence of competing designs, the market registered an impressive growth worldwide, leading to the emergence of large producers, first in European pioneer countries and later in Asia. There is intensive competition between firms with different technologies, including some that are already being mass produced $\left(1^{\text {st }}\right.$ and $2^{\text {nd }}$ generation $)$ and some emerging ones that seek to address existing efficiency and cost problems. In Portugal the sector registered a boom in recent years, mostly based in decentralised grid-connected small systems, even if some large power plants have also been set up and account for a substantial proportion of installed capacity (around 70\%). A number of new large players have emerged, but most of them are not involved in new technology development: they are cell/module manufacturers (usually under license) or system integrators/installers based on third party technologies, some combining it with plant operation or maintenance. In parallel, a number of small companies, developing new generations 
of technologies, started to emerge from university research. The firm in the case studies is one of them, being one of the few already in the market.

Ocean wave technologies only recently started to move from the R\&D to the early stages of industrial development. Technological uncertainty is still very high, since it is not yet established which systems can be more effective in producing electricity efficiently while withstanding the ocean conditions. Thus there are a number of competing systems, some still in prototype stage, some approaching commercialisation, which are currently being tested at experimental settings in various locations. Portugal, given its natural conditions (large Atlantic coast) its favourable policies, the expertise developed by some universities and the interest revealed by local energy companies, emerged as an attractive setting for experimental installations, led by both Portuguese and foreign firms (namely UK firms that lead the field). Two of the firms in the case studies operate in this field, although with different activities.

\subsection{Firms' histories}

\section{Ocean}

OCEAN is an engineering company, created in 2005, that offers a range of solutions in the field of wave energy, from project management to systems design and supply chain development, including operation and maintenance. The firm specialises in the OWC (Oscillating Water Column) technology and has developed a number of technologies in this field. These technologies are the basis for the firm core activity: the conception and development of customised systems.

OCEAN was created by a team that put together scientists with a longstanding experience in hydropower and wave energy - who were among the pioneers of the wave field in Portugal - and engineers with previous experience in engineering companies. The group of scientists had also been involved in an early experimental project for the installation of wave energy systems in Portugal: the Pico Pilot Plant in the Azores islands. This involvement was the driver for the creation of a new firm to develop project-related and system maintenance service activities in the field, first to the Pico Plant and later in the context of other projects in Portugal and abroad. In addition to the highly specialised service activities, the firm also started developing its own technologies, in collaboration with universities, including the university of origin of the scientists (who maintained their jobs). These technologies have been patented and customised products have already been developed for specific clients involved in the installation of experimental/ demonstration wave energy systems in Portugal and abroad. More recently the expertise gained in the conception and installation of ocean systems enabled the firm to extend its activities to the offshore wind energy production, through the 
participation in an experimental project in this field. Both the research that led to the development of firm's technologies and the experimental/ demonstration projects in which the firm participates, have been funded by national and European programmes, often involving academic and industrial partners.

The dual origin of the entrepreneurs provided the new firm with different sets of competences (science, engineering, management) and also with different sets of networks. The scientists' networks were critical for the establishment of formal relationships with universities, enabling access to laboratories, equipments and human resources, besides permitting the informal access to new knowledge. They equally facilitated the integration in European research projects, which provide both funds for research and international contacts. On the other hand, the experimental background of the scientific team provided them with hands-on experience in the implementation of actual projects and longitudinal data on their functioning. It also permitted them to establish relationships with other key actors in the Portuguese wave energy milieu, in particular the Portuguese energy utility and a large energy equipment producer. These were involved in the Azores experimental plant and maintained an interest in the field, participating in other projects and being currently involved in the launch of the Portuguese pilot zone for wave energy systems. The entry into this network was also critical for the expansion of the firm's activities to offshore wind projects, where these same actors are involved.

On the other hand, research networks together with the extensive contacts established by the nonacademic elements in engineering firms, were instrumental for the participation of the firm in new demonstration projects being launched in other countries (in particular the UK and Ireland). Given the stage of development of the field, integration in networks that grant access to experimental / demonstration projects is critical, since this is the sole market for a small supplier of technologies and services and also provides a sheltered test-bed for the technologies it is developing. The non-academic group adds its strong engineering experience that is critical for the practical aspects of project management and product development. It is also responsible for the concretization of the commercial opportunities - where both their previous experience and their networks and individual reputation are instrumental.

The firm and some of its entrepreneurs at an individual level, have been consistently involved in the promotion of ocean energy at country level, both in terms of research and in terms of an effective coordination of technology development efforts. They were namely active in the creation of a dedicated technology centre that involves universities and several companies active in the field. 


\section{$\underline{\text { Wave-Tech }}$}

WAVE-TECH is a recent start-up, created in 2009, that has developed and patented a new and more efficient process for transforming kinetic energy into electricity: an Electric Spherical Generator (ESG). The characteristics of the system (compact and adaptable to any size) made it suitable for different market applications. It was decided to initially focus on the wave energy field, where the system emerged as particularly effective and competitive with existing solutions. A product is currently being developed (prototype stage): a floating structure for capturing energy from waves, having the ESC at its core, which is also patented.

The process of WAVE-TECH formation is substantially different from that of OCEAN. It was created by a team of young university students from different fields (mechanical and electrical engineering and management) whose objective was to develop a more efficient system for converting movement into electricity, initially conceived to be a charger for small electronic equipments. Thus, the starting point was not the wave energy field. It was only after they developed a first small generator and won a number of entrepreneurship and business ideas contests that the opportunity to apply it to wave energy production arose. The technology was then reconfigured in order to answer to the harsh demands of the new application field. Regarding the new application, the turning point was the $1^{\text {st }}$ place in the innovation contest promoted by the energy utility, that provided a financial prize to support the creation of a start-up company and the technical development of the project, and also included technical support from the utility own laboratories. This prize was critical for the new firm, since it brought its technology to the attention of the energy utility, which has a great interest in ocean energy technologies, thus facilitating subsequent access to testing facilities and to the local market for wave energy projects.

Thus, the definition of the actual market opportunity to be exploited was a process that received important contributions from experienced researchers from the universities of origin of the entrepreneurs (who currently compose the scientific advisory board), as well as from a technology transfer organization in the wave energy field and from the energy utility. The development and first tests of the wave energy system took place in close collaboration with the same organizations. The young team was thus able to compensate for the absence of business experience and the limited research background of its members by developing relationships with relevant academic and business players.

The ability to congregate a variety of competences around this project was largely due to innovative nature and unique characteristics of the technology, which were recognized in a variety of business idea and innovation contests where the company obtained first prizes. This draw the attention of the 
media, creating "a buzz" around the technology that was used by the entrepreneurs to raise the interest of the market and potential partners. These contests were also an important source of seed capital and provided additional resources such as business training/tutorials. As a result of one of these contests the company was invited to spend a period at a technology incubator located in Silicon Valley. This stay was supported by a large supplier of energy equipment not yet operating in the wave field, which may have regarded this association as a way into it. The company regards this stay as providing the opportunity for a wider diffusion of its technology and for expanding its international network of contacts among potential clients. In fact, its goal is to produce and sell the wave energy generator worldwide. On the other hand, it is aware of the wide potential of its core technology - the ESG - and is planning to license it to other potential markets.

\section{Wind-Tech}

WIND-TECH, created in 2003, operates in two main fields: aerospace technologies and energy systems. Regarding the energy business it defines it as focusing on energy conversion systems and is currently operating in two main fields: energy and gas storage and high altitude wind conversion. The dual focus aerospace/energy is relatively unusual, but has a relevant impact on the activities conducted in the energy field. In fact, the technologies being developed combine knowledge of airborne structures and unconventional means of propulsion, with energy transfer forms. The firm is focused on upstream technological development with a view to producing intellectual property assets that will subsequently be licensed to other organisations.

The firm originated from aerospace research - its founder worked in the European Space Research and Technology Centre (part of the European Space Agency - ESA), where the firm was initially incubated. The entrepreneur decided to establish the company in his home country and upon returning to Portugal benefited from the support of a number of Portuguese universities and research centres that provided a second incubation environment, granting access to their laboratories and equipments and also providing human resources.

The early activity was on areas related with the entrepreneur research at ESA, having this organization as the main partner and also client. Thus space-driven technologies, in particular those related to the storage area, were the first focus, resulting in a number of patents. The space industry is currently the main market, with particular relevance for ESA which remains a key client and an important source of industrial contacts. The activities conducted in this area may in the future also have some potential for other types of market, such as the automotive industry (CO2 storage/recycling) or other sectors seeking advanced gas storage solutions. 
However, research was also conducted in the field of high altitude wind and this area has recently become a flagstone of the company. Partly drawing from the knowledge and competences developed in the space field, WIND-TECH conceived and patented a new system that can capture energy from very low altitude wind, using the aerodynamic forces acting upon an airborne craft. Research is currently on-going, funded both by national sources and by the 7FP. The latter is led by WIND-TECH and involves collaboration with Portuguese and European research organizations as well as industrial partners, including the Portuguese old energy utility. High altitude wind conversion still faces a number of complex technological challenges, but the firm believes that the concept under development can put them at the forefront of this new field.

\section{$\underline{\text { Wind-Serv }}$}

WIND-SERV, created in 2004, is a consultancy company that specialises in wind resource assessment services based on advanced wind modelling techniques. It offers a range of services from site evaluation to wind resource assessment studies including planning, wind measurement campaigns and project due-diligence. The company also started providing consultancy in other renewable energies where its assessment competences are also applicable (e.g. large solar power plants), although this business has a much smaller weight.

The company was created by a team of senior university researchers with extensive experience in the wind field. Previously to creating the company they combined their academic activity with research and managerial activities in a research and technology transfer organisation that has been actively involved in the development of the Portuguese wind industry, from its inception. The exposure to the industry's activity enabled them to identify a market for this type of services and to anticipate its growth, given the expected expansion of wind power plant installation. The low career expectation at the university (given the precarious positions occupied) further encouraged the members of the team to pursue with this project. Two of the entrepreneurs had an MBA and one had previous business management responsibilities at the parent organisation, which provided the team with a reasonable set of managerial competences.

However, the creation of the new company was regarded with some hostility by the parent organisation. Therefore subsequent $R \& D$ activities were conducted in collaboration with other organisations, although informal connections were maintained with some colleagues. The collaboration with two Portuguese universities led to the development of more sophisticated wind assessment techniques such as mesoscale modelling and computational fluid dynamics (CFD) simulations, which put the company the company at the forefront in its field. The firm was installed in a S\&T park associated with the university. 
The contacts established by the entrepreneurs with the firms involved in the early wind energy projects facilitated access to the main players in the industry (both old and new) and led them to become a key partner to energy producers, equipment manufacturers and plant installers. They were also actively involved in the promotion of renewable energies at country level and become members of national and international trade associations of the sector. This positioning and contacts also enabled the firm to develop an international reputation and to start internationalising its activities, both for Europe (namely Eastern Europe) and for Brazil and Portuguese speaking countries in Africa, where subsidiaries have been created.

\section{$\underline{\text { Solar }}$}

SOLAR, crated in 2006 is a solar photovoltaic company that develops, manufactures and installs PV systems, with a focus on distributed systems (residential, commercial or industrial). The company is positioned in the emerging area of solar concentration where it competes with products resulting from in-house R\&D. It has recently completed the development and is starting to commercialise a new high-efficiency PV system designed to reduce the solar cell usage in 95\% (thus bringing solar electricity costs close to those of conventional systems), with which it expects to occupy a leading position in the new concentrating PV (CPV) market. In addition, it also commercialises third party products, which enables it to offer a range of solutions that match clients' requirements. For this purpose it developed an innovative on line sales model that allows the client to choose the best combination of services and equipment at the best prices.

The company was created by two young physicists who applied the knowledge developed during their doctoral / post doctoral studies in the conception of an innovative CPV system. The project answered to the challenge of doubling the yield of traditional PV systems, put forward by a foreign solar research company. The resulting prototype won a major business ideas contest, which afforded visibility to its innovation and also provided the initial seed-capital. Additional funding for R\&D and company set-up was obtained from a government entrepreneurship programme. The new firm was incubated in a S\&T park associated with the parent research organisation, where a first pilotinstallation was tested. The participation in a number of business idea contests and entrepreneurship programmes also assisted the entrepreneurs, who did not have a management background, to define more clearly their business and to identify potential partners. Over time, the firm continued to receive prizes and distinctions awarded by a variety of national and foreign organisations, whose signalling function contributed to the promotion of its activities.

The first product, which was patented by the firm, was followed by a sequence of other innovations, both at product and process level, culminating in the technology being currently introduced in the 
market. The latter is now being tested in a larger (mini-generation) setting, in collaboration with a large industrial company. In order to sustain this innovative stance the firm maintained a strong research orientation. Over time it built in-house $R \& D$ capabilities, but research also involved close collaboration with Portuguese and foreign research organisations, often benefiting from the support of public incentive programmes.

The firm started to address the international market from the early stages. The fact that the first product answered positively to the challenge mentioned above meant the firm was invited by the foreign challenger - who later become a key partner - to install one of the fist European CPV power plants. This first step opened a door to the local market, which still is one of the most important outlets for the company products. Entry was further facilitated by the good knowledge possessed by one of the entrepreneurs of the country cultural and institutional setting, particularly relevant in a sector strongly influenced by policy decisions. The internationalisation pursued to several southern European countries, and in 2008 the company entered the US market. Nowadays the firm operates in European and non-European markets and expects to boost its international sales with the new CPV system. International operation takes place through partnerships with local companies that act as representatives, or manufacture its products under license.

The strong international orientation since an early stage can also be explained by the fact that solar PV only become a fundamental part of Portuguese energy policies by the end of the decade, the emphasis being then put on large power plants. Thus while some foreign markets showed a great potential for a firm with highly innovative technologies, the national market was very incipient, in particular for the type of systems offered by SOLAR. The national market only became a target at a later stage, when the introduction of incentives for micro-generation boosted demand for decentralised PV systems. The firm established partnerships along the value chain for production and commercialisation, from manufacturers to installers/system integrators, including a number of reputed international producers of cells and modules, which are included in the range of solutions offered to its clients. More recently the firm applied to the first government bid for licenses to install CPV power plants, but was not selected despite being one of the few firms competing with own technologies, which may hinder a wider national strategy.

SOLAR has also been involved in the promotion of the field at national level. It integrated a coalition of new entrants - that included the majority of the large players involved in solar PV (installers \& equipment manufacturers) - which joined efforts to promote (and lobby on behalf of) the development of a national market for solar PV. Recently it also participated in the setting-up of a research centre dedicated to solar energy that involves universities and key industrial players. 


\subsection{Relationships established in the access to resources}

The cases studies enabled us to obtain in-depth information on the decisions made by the firms concerning de access to a set of key resources and competences and on the activities conducted in order to obtain them, including the nature of the relationships established for this purpose. This information permitted to uncover the key actors involved in the process of opportunity identification and resource access and to grasp the roles they played in the access to the resources necessary for the start-up process and in the firms' early development. The results are summarized in Table 4.

Table 4 - Relationships by type of resource

\begin{tabular}{|c|c|c|c|c|c|}
\hline & WAVE-TECH & OCEAN & WIND-TECH & WIND-SERV & SOLAR \\
\hline $\begin{array}{l}\text { Opportunity } \\
\text { identification/ } \\
\text { shaping }\end{array}$ & $\begin{array}{l}\text { Utility } \\
\text { University } \\
\text { professors }\end{array}$ & $\begin{array}{l}\text { Personal networks in } \\
\text { industry }\end{array}$ & $\begin{array}{l}\text { International } \\
\text { agency (parent) }\end{array}$ & $\begin{array}{l}\begin{array}{l}\text { University } \\
\text { (experience) }\end{array} \\
\text { Personal networks } \\
\text { in industry }\end{array}$ & $\begin{array}{l}\begin{array}{l}\text { University } \\
\text { (research) }\end{array} \\
\text { Foreign solar } \\
\text { research firm }\end{array}$ \\
\hline $\begin{array}{l}\text { S\&T } \\
\text { knowledge } \\
\text { (including } \\
\text { facilities) }\end{array}$ & $\begin{array}{l}\text { PT University } \\
\text { (parent) }\end{array}$ & $\begin{array}{l}\text { PT Universities } \\
\text { (parent \& other) } \\
\text { Network from } \\
\text { European RTD } \\
\text { programs }\end{array}$ & $\begin{array}{l}\text { PT Universities } \\
\text { International } \\
\text { agency (parent) } \\
\text { Network from } \\
\text { European RTD } \\
\text { programs } \\
\text { Utility } \\
\end{array}$ & $\begin{array}{l}\text { PT Universities } \\
\text { S\&T park }\end{array}$ & $\begin{array}{l}\text { PT and foreign } \\
\text { universities (parent } \\
\text { and others) } \\
\text { S\&T park }\end{array}$ \\
\hline $\begin{array}{l}\text { Technology } \\
\text { testing }\end{array}$ & $\begin{array}{l}\text { Utility } \\
\text { TT organization }\end{array}$ & $\begin{array}{l}\text { Utility } \\
\text { Equipment mft } \\
\text { Network from } \\
\text { European RTD } \\
\text { programs } \\
\end{array}$ & $\begin{array}{l}\text { International } \\
\text { agency (parent) }\end{array}$ & & $\begin{array}{l}\text { S\&T park (project } \\
\text { involving Utility) } \\
\text { Foreign solar } \\
\text { research firm } \\
\text { Large industrial user }\end{array}$ \\
\hline $\begin{array}{l}\text { Business } \\
\text { competences } \\
\text { \& advice } \\
\end{array}$ & $\begin{array}{l}\text { Entrepreneurship } \\
\text { programs } \\
\text { Business angels }\end{array}$ & & $\begin{array}{l}\text { Entrepreneurship } \\
\text { programs }\end{array}$ & & $\begin{array}{l}\text { Entrepreneurship } \\
\text { programs }\end{array}$ \\
\hline Financial & $\begin{array}{l}\text { Utility (prize) } \\
\text { Public agencies }\end{array}$ & Public agencies & Public agencies & Public agencies & $\begin{array}{l}\text { Prize awarders } \\
\text { Public agencies }\end{array}$ \\
\hline Legitimacy & $\begin{array}{l}\text { University } \\
\text { Utility }\end{array}$ & $\begin{array}{l}\text { University } \\
\text { Network from } \\
\text { European RTD } \\
\text { programs (abroad) } \\
\text { Industry associations } \\
\text { Sectoral research } \\
\text { organisation } \\
\text { Collective action } \\
\end{array}$ & $\begin{array}{l}\text { International } \\
\text { agency (parent) } \\
\text { Network from } \\
\text { European RTD } \\
\text { programs }\end{array}$ & $\begin{array}{l}\begin{array}{l}\text { University } \\
\text { (reputation) }\end{array} \\
\text { Personal networks } \\
\text { in industry } \\
\text { Industry } \\
\text { associations } \\
\text { Collective action }\end{array}$ & $\begin{array}{l}\text { University } \\
\text { Prize awarders } \\
\text { Foreign solar } \\
\text { research firm } \\
\text { Sectoral research } \\
\text { organisation } \\
\text { Collective action }\end{array}$ \\
\hline $\begin{array}{l}\text { Access to } \\
\text { market }\end{array}$ & $\begin{array}{l}\text { International } \\
\text { program } \\
\text { (university) }\end{array}$ & $\begin{array}{l}\text { Personal networks in } \\
\text { industry }\end{array}$ & $\begin{array}{l}\text { International } \\
\text { agency (parent) }\end{array}$ & $\begin{array}{l}\text { Personal networks } \\
\text { in industry } \\
\text { Previous clients }\end{array}$ & $\begin{array}{l}\text { Foreign solar } \\
\text { research firm } \\
\text { Previous clients }\end{array}$ \\
\hline $\begin{array}{l}\text { Market } \\
\text { relations }\end{array}$ & & $\begin{array}{l}\text { Equipment mft } \\
\text { Utility } \\
\text { Foreign wave } \\
\text { companies } \\
\text { Suppliers } \\
\text { (components \& } \\
\text { materials) } \\
\end{array}$ & $\begin{array}{l}\text { International } \\
\text { agency (parent) } \\
\text { [others in space } \\
\text { area] }\end{array}$ & $\begin{array}{l}\text { Wind energy or } \\
\text { wind-related } \\
\text { companies (PT } \\
\text { and foreign) } \\
\text { Suppliers } \\
\text { (complementary } \\
\text { competences) } \\
\end{array}$ & $\begin{array}{l}\text { Foreign solar } \\
\text { research firm } \\
\text { Firms upstream \& } \\
\text { downstream value } \\
\text { chain (PT \& } \\
\text { foreign) } \\
\text { Foreign licensees } \\
\end{array}$ \\
\hline
\end{tabular}

In this paper we are particularly concerned with the process of market introduction of the technology. Therefore, we will present a very generic overview of the situation concerning access to the basic resources that determine firms' ability to conduct that process - knowledge, capital and legitimacy and will subsequently focus on the relationships/actors more directly associated with market entry. 


\subsubsection{Grounding the new firm: early access to knowledge and finance}

All firms mentioned to have strong relationships with universities and other research organizations and acknowledge their relevance for knowledge access, not only in the start-up stage, but also for the continued development of their technologies. The parent organization usually plays an important role - which is typical of spin-offs (Mustar et al, 2006) - but in most cases the firms also establish, from an early stage, relationships with other research organizations, which in some cases end up becoming the key research partner. Portuguese universities play a central role in firms' knowledge networks. In addition, in emerging fields, firms also integrate international research networks usually in the context of European RTD projects, which frequently also involve Portuguese universities. These networks are also relevant for the subsequent commercialization of the technologies, since they provide contacts with advanced companies leading demonstration projects. Finally in emerging (ocean) and developing (solar PV) fields, firms or their entrepreneurs participate (and sometimes led the creation of) dedicated research and technology diffusion organizations involving both universities and companies that have a dual role, typical in the construction of a new field (Schot and Geels, 2007): technological development on one hand, endorsement of the technology and promotion of the field on the other.

Universities also play a number of other roles, particularly in the pre-start-up and start-up stages. All but one firm had submitted patents. In some cases the technology was developed at the university, patented and then licensed to the firm. In the other cases the University TT offices assisted in the process of intellectual property (IP) protection. Universities (and not exclusively the parent) also play other roles: access to facilities (equipment, laboratories and sometimes premises or access to the associated incubators or S\&T parks), including for some technologies, conditions for testing at prototype or even pilot level; support to the participation of ideas or entrepreneurship contests; access to business training.

Reputed universities are also a source of scientific credibility which is particularly relevant for young scientists, since senior ones often rely on their own reputation and networks to signal quality (Grimaldi and Grandi, 2003). Entrepreneurs also benefit from the industrial connections of university teams, both in established and in emerging technologies. In all cases, previous exposure to an application oriented environment and the experience it provided to the entrepreneurs (case of senior scientists) or the teams to which they were connected (case of young scientists) was critical in the identification or the further shaping of the business opportunity that led to firm creation.

Capital is another key resource for firms exploiting new technologies, even if capital needs differ according to the stages of development and the nature of the firms' business. None of the firms analysed in the cases studies has attracted external capital, although one is involved in negotiations 
with business angels. This is not atypical of small technology intensive start-ups (Lockett et al, 2002) and forces firms to resort to a variety of alternative sources of finance. At start-up stage several firms in particular those created by young entrepreneurs - draw on the prizes from a sequence of entrepreneurial contests that act as seed-capital and often also provide business advice and support in the development of business competences (Kay, 2012). They also rely on formal or informal links with universities (namely, but not exclusively, the parent) that facilitate access to facilities and human resources and reduce the costs associated with knowledge production (Clarysse et al, 2005). A similar "incubator" role was also played by other organisations: e.g. other universities (case of WIND-TECH when the company moved to Portugal); S\&T parks (case of SOLAR first pilot-plant) and even the exutility (case of OCEAN-TECH prototype development). Participation in national or European RTD programmes is also a key source of funding for research and innovation. It sustains the development of the first technology, in particular for these firms whose technologies are more distant from the market. But it remains important over time, for the development of subsequent technologies/products. Finally, established companies can provide resources for R\&D and technology experimentation, through research and technology development contracts (case of OCEAN or SOLAR).

\subsubsection{Building legitimacy}

Legitimacy is a critical asset for firms without a previous track record that are introducing new technologies not yet validated by the market. External endorsement by reputed individuals or organisations can be determinant in building such legitimacy. Association to reputed actors in science, in industry and in political positions, or their active intermediation on behalf of the new firm, can ease some of the difficulties it is likely to experience in entering the market and/or in establishing relationships that support the development and/or commercialisation of the technology. Thus, it was considered relevant to assess the nature of the relationships that the entrepreneurs regarded as having a credibilitization or mediation role.

Firms developing emerging and stabilised technologies were found to need different types of endorsement and to resort to different actors for this purpose. Firms involved in emerging technologies need to gain access to scientific knowledge and also to experimental settings and thus value organisations/individuals that signal technological quality and that have good contacts in the (largely international) networks of organisations involved in research, demonstration and early use of these technologies (case of OCEAN or WIND-TECH). Firms in developing technologies like solar PV need to combine technology signalling with market endorsement. Thus while technology signalling is critical, they value particularly organisations that combine both (case of SOLAR). Finally, for firms in more stabilised technologies, industry contacts and market endorsement through references to previous work are the most critical (case of WIND-SERV). It should also be pointed out 
that technology signalling is particularly critical for firms selling or licensing the technology, given the information asymmetry between buyer and seller. This was the case with SOLAR in some foreign markets and is also the case with WIND-TECH that intends to sell IP rather than products.

But the extent to which firms need to resort to external endorsement depends on the background of the entrepreneurs (Mangematin et al, 2002), as becomes evident among this group of firms. Thus, there are differences between senior and young researchers: as pointed out above, the former rely more strongly on their personal reputation to signal the quality of the technology, while the latter rely more on the reputation of the parent organisation or other universities they associate with. Establishing an advisory board composed of reputed scientists was a way to capitalise on that reputation. Young scientists also draw on additional sources of legitimacy such as prizes in prestigious entrepreneurship or innovation contests or success in obtaining public funding for research (Rao et al, 1994).

There are also differences between teams combining scientific and business competences, or whose entrepreneurs were previously involved in industry-oriented activities; and teams exclusively composed of academic scientists with little or no industrial exposure. The former, which also more frequently composed of senior researchers, resort more extensively on their personal networks in industry to gain access to clients or industrial partners (case of WIND-SERV or OCEAN). The latter use forms of technology signalling as the starting point (patents, university connections) and attempt to gain the interest of influential companies that can subsequently endorse them to clients, partners or sources of funding or can be used as references (case of WAVE-TECH or SOLAR). Scientific networks (in particular international ones) are important in both cases, since they frequently encompass university/industry consortia (case of OCEAN or WIND-TECH).

Finally, it is relevant to point out that involvement in collective action on behalf of the technology or the industry is also a source of visibility for the firm, besides being critical for the wider acceptance of the technologies being commercialised. This visibility is twofold, since it contributes to boost its reputation among the industry players and signals the company to other actors. These types of activities have been pursued by the two senior teams (OCEAN and WIND-SERV), but SOLAR which have now an innovative and industrial record that provides it with some reputation - have more recently also engaged in this type of activities.

Table 5 summarises the above discussion, highlighting the nature of the legitimacy building relationships established by the firms in the cases studies, according to the stages of development of their technology and the of background of their entrepreneurs. 
Table 5 - Legitimacy building relationships by entrepreneurs' background and technology maturity

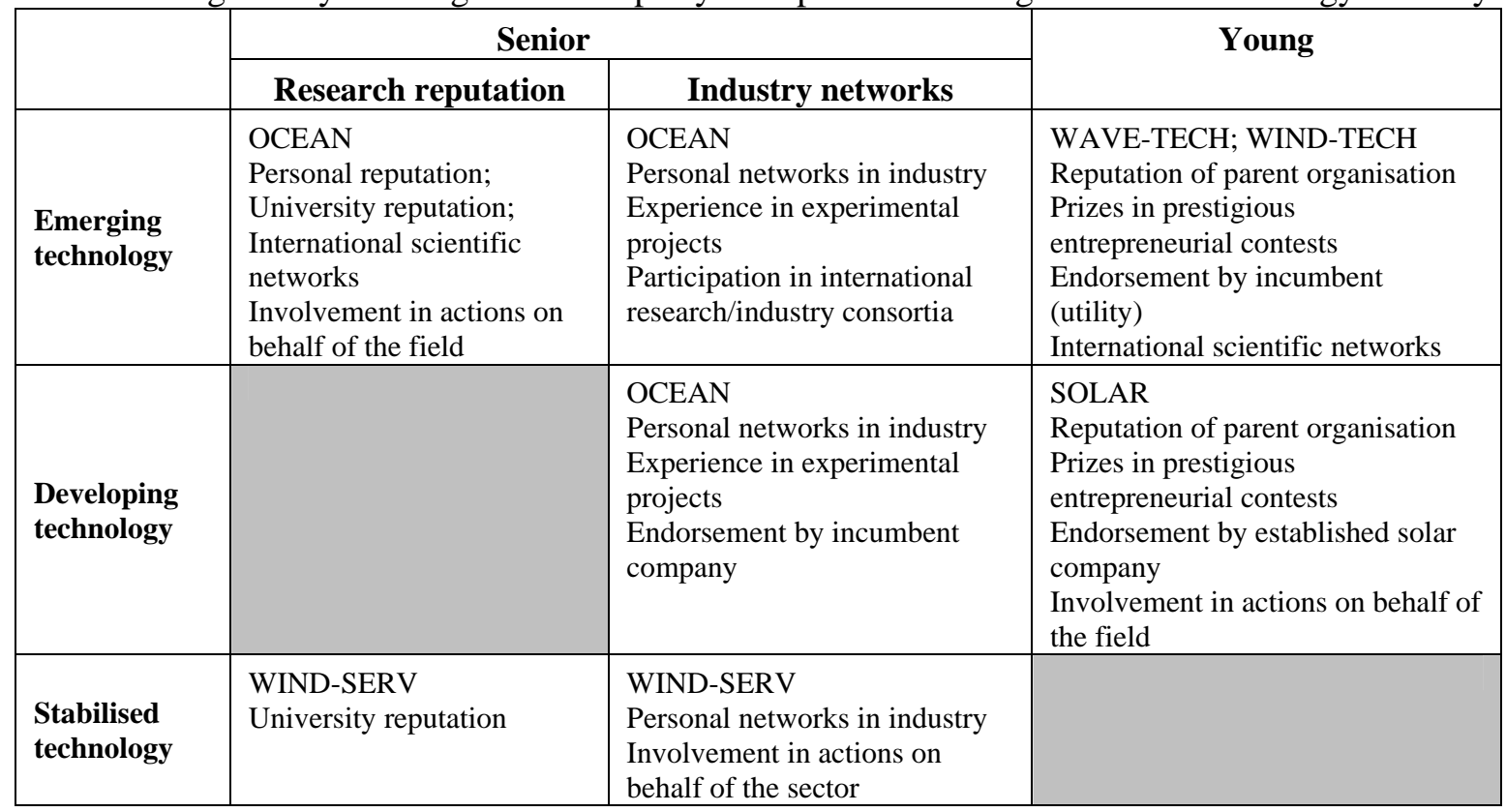

\subsubsection{Commercialising the technology: market-related assets and relationships}

The process commercialisation of the technology requires firms to gain access to a number of downstream resources - technological (for test and demonstration) and non-technological - related to market access and market-oriented activities. At these levels, relationships with other firms are central, both for firms entering the market and for firms still developing their technologies. But they assume a diversity of forms, according to fields and technologies. It is therefore pertinent to look in greater detail into relationships that concern the process of market introduction of the technology and, in particular, the position and role played by incumbents in this process.

One first conclusion that can be reached from an analysis of the relationships established by firms for the market introduction of their technologies is that differences can be observed between firms exploiting technologies with different levels of maturity - which may be partly explained by the level of technological and market uncertainty; but differences are equally observed among firms exploiting technologies in similar stages of development - which may be related with differences in the types of resources necessary for their exploitation and the sources of these resources. This variety suggests that these firms are confronted with different commercialisation environments (Gans and Stern, 2003), which, as argued above, will influence the strategies adopted in the market exploitation of new energy technologies. 
Thus, in order to understand the decisions made by firms concerning the nature of the relationships established in the process of commercialisation of their technologies we will have to take in consideration of commercialisation environment faced by them. In fact, as discussed in sections 4.2 and 4.3, new firms are confronted with a since characterised by fast technological development and strong incumbent power. Thus, the nature and composition of their relationships will be influenced by two main aspects: the need for and relevance of complementary assets possessed by incumbents for capturing the value of their technology, and the positioning of the latter relatively to the technology exploited by the new firm, i.e. whether the technology is relevant for them and whether the firm can preclude its appropriation.

We will subsequently address the process of commercialisation of the technologies introduced by the firms in the case studies along these lines. In conducting this analysis we take into consideration, first of all, the nature of the technology being introduced and the industrial structure of the segment where the firm operates. These are basic dimensions that simultaneously shape the opportunities open to the firms and condition their decisions on the mode of exploitation of these opportunities. They will enable us to gain a first understanding of the commercialisation environment and thus provide a framework against which we can assess firms' behaviour. This includes an assessment of the nature of the assets required by the new firms to capture the value from their technologies and the conditions in which these assets can be accessed and deployed in the specific energy segment they are targeting. In particular, of whether some of the key complementary assets are possessed by incumbents and in which conditions firms can gain access to them. It also includes an assessment of whether the technology being introduced by the new firm is relevant for the incumbents and thus which is their attitude towards the technology and its supplier(s). Finally, an assessment of whether the new entrants have the capacity to protect their technology from expropriation

We will start by looking at the capacity to protect the technology, since all the firms studied are, at least in principle, in a similar position. In fact, all but one of the firms have the core technology protected by patents, which are generally regarded as the most effective appropriability mechanism in the case of small technology suppliers (Arora and Merges, 2004). The one that did not patent the technology benefits from the protection afforded by the tacit and experiential nature of the knowledge base. This firm (WIND-SERV) offers specialized services that draw on a range of methodologies and competences whose development and deployment is based on firm-specific knowledge, largely embodied in expert individuals. This type of knowledge is difficult to imitate and thus can afford protection, in particular when combined with continued research to improve the methodologies applied. Some of the other firms combine patent protection of the core technology with similar nonpatent mechanisms, thus reinforcing their appropriability position (Hurmelinna-Laukkanen and Puumalainen, 2007). It is therefore possible to assume that these firms had conditions to exclude 
others from imitating their technology, thus retaining the capacity to establish market relationships with incumbents or even to compete with them ${ }^{8}$. We will subsquently address the commercialisation process followed by each firm.

OCEAN and WAVE-TECH, that operate in the wave field, are introducing technologies still in a very immature stage, which require extensive testing, first at prototype and later at pilot stage, in real life conditions. These experiments involve complex infrastructures and extensive financial resources that are beyond the reach of a small firm, being often possessed by large firms or consortia that lead large scale demonstration projects. For OCEAN, access to these settings is critical, since it provides a market for its products and services and simultaneously a test bed to improve its technologies. In other words, in order to develop and exploit its technology the firm needs to gain access to complementary assets co-specialised to the innovation that are possessed by large incumbents operating in the field. Those incumbents show interest in the technology being commercialised and are prepared to get involved in its testing and validation. Thus OCEAN has to establish alliances with the owners of the co-specialised assets in order to enter the market and commercialise its technology. However, because there is still extensive experimentation and no dominant design has emerged, there are several competitive projects underway. This provides OCEAN with opportunities for establishing relationships with different partners, the main challenge being to capture their interest in a context where there are also several other small suppliers with competing technologies. The fact that OCEAN emerged within the Portuguese "wave energy network" was instrumental in this process, since it benefitted both from the scientific reputation and from the extensive contacts established by the entrepreneurs to gain access to experimental settings at national and international level. Thus the firm was able to establish a close relationship with local energy incumbents (both the ex-utility and an equipment manufacturer) that have a strategic interest in ocean technologies and thus provide a market for technologies and skills that can be applied both to wave energy and offshore wind. But it was also able to establish relationships with foreign companies that lead the wave sector and to participate in consortia involving several public and private actors conducting experimental projects in Portugal and abroad. Thus OCEAN capitalized on the still turbulent nature of the sector to propose its technology and extensive skills to different partners, deflecting the risks of exclusive relationships.

A similar reasoning may apply to WAVE-TECH, which is still developing a prototype, in its future efforts to introduce its innovative wave technology. The main issue in this case concerns the extent to which the new technology being introduce will require the same degree of integration with incumbent

\footnotetext{
${ }^{8}$ The presence of patents may facilitate the commercialisation of the technology. In fact they enable the supplier to disclose more detailed information on the technology, without running the risk of expropriation, thus reducing the asymmetry of information that characterise technology transactions (Arrow, 1962) and lowering the transaction costs for both suppliers and buyers (Gans et al, 2002).
} 
experimentation and production assets to obtain a final product, since the technology is presented as having a greater autonomy. This will ultimately condition the positioning to be adopted by the firm. In any case, the incumbents' attitude relatively to the technology is likley to be different. In fact, contrary to OCEAN, this firm emerged outside the "wave energy network" with a technology that departs from the configurations in which the local incumbents are currently involved. Nevertheless, we observe an interest of the ex-utility in watching the development of a technology that deviates from its core competence, but appears to have some potential. This is materialised in some contribution to its development (seed capital, access to facilities and human resources), as well as advice and credibilisation. That is, the large incumbent is offering access to some key assets that will enable the new company to complete the development of the technology. On the other hand, we observe a strong reliance of the new firm on the "benevolent" interest of the influential company. However, its search is not confined to the local market and it is profiting from the visibility afforded by wining a series of entrepreneurship contests to gain access to an international incubator that can provide it with a wider range of potential alliances. The firm plans to manufacture its core product and eventually license the technology for other applications. Once it engages in these activities it will have to make some new decisions regarding the type of relationships to establish.

The case of WIND-TECH that is also introducing an emerging technology, presents an interesting contrast. First of all, because WIND-TECH opted for focusing on the development of the technology and licensing the intellectual property, thus avoiding the need to build production and commercialisation assets altogether. Second, because high-altitude wind possibly is at an even earlier stage of development than wave energy, and thus the essential of the relationships WIN-TECH established so far concern R\&D activities. While this does not mean that the development and experimental test of the new technology will not entail the access to additional competences that require other types of alliances, so far these relationships are taking place in the context of a European funded RTD consortium (involving public and private organisations) led by WIND-TECH. Finally, because the technology that is being developed is much outside the competences of local incumbents. Indeed, the genesis of the company was an international organization in a different field (space) that remains a key partner, being a source of knowledge and contacts. However, the ex-utility integrates the European consortium where the technology is being developed, denoting some interest in keeping a watch on a technology that is a potential extension - or even a competitor - to its core wind area.

The case of SOLAR is substantially different from the previous ones. The company is introducing a new technology in a field characterized by the presence of several generations of technologies with different levels of market penetration and also with different sources of competitive advantage. However, since there is still great need for cost and efficiency improvements there is scope for new solutions that answer to these problems and for new entrants proposing them. Thus Solar PV is a 
turbulent market characterised by fast technological change, where entry barriers are low (at least in some segments of the value chain) and thus small independent entry with highly innovative technologies is viable and frequent. The particular technology being introduced (CPV) is regarded as providing an effective answer and SOLAR was one of the companies pioneering its commercial introduction. Therefore SOLAR profited from its innovative technology to enter the market directly with a final product, targeting the distributed segment (decentralized grid connected small scale systems supplied to residential or commercial/industrial end users). For this purpose it manufactures its core product, while acquiring outside some key components and the complementary elements of the so called "balance of systems", fact that solar PV industry is organized in a value chain mode and thus the final product requires integration of upstream and downstream elements. However, these elements can generally be found in the market in competitive conditions. Thus incumbents do not control the assets necessary for commercialising the technology, which are usually accessible through arms' length relationships, even if in some cases alliances can be important to guarantee supply or reinforce market positions, particularly in the case of a new small company.

The decisions made by SOLAR regarding alliances are therefore based on an evaluation of the benefits that can be obtained from a combination of arms' length market relationships and closer partnerships, for different purposes and in different market conditions. At start-up the main problem of a company with a new product is to convince its potential clients of the advantages of the technology as compared with competitor designs. Thus the establishment of a partnership with a foreign research oriented solar company interested in new solutions was instrumental, providing a first opportunity to achieve a real-world installation. It also endorsed the subsequent commercialisation, thus affording both legitimacy and market contacts.

This was particularly valuable because it enabled the company to enter a foreign market when the national market was still very incipient. With the introduction of incentives for solar PV and to "micro-generation" systems, the national market - and in particular the market for distributed systems - registered a sudden growth. Currently, there is intense competition between different firms commercializing different types (and generations) of technologies/systems. They include the few firms that have developed own technologies, a variety of distributors of third party technologies and also large new entrants in the solar business. The latter specialize in systems installation but tend to commercialise competing technologies (usually earlier generations). Some of them focus on larger centralised systems (which at some point were favoured by solar energy policies), but others compete

\footnotetext{
${ }^{9}$ Refers to system components apart from the photovoltaic modules, consisting namely of panel mounting equipment, monitoring devices, inverters, connectors, charge controllers, batteries, grounding hardware, lightning protection equipment, etc. (Kirkegaard et al, 2010)
} 
in both areas: centralised and distributed systems. Thus, there is limited scope for partnerships, apart from distribution contracts. In the market for distributed systems, SOLAR competes directly with the three types of companies, deriving some competitive advantage from its innovative products and from the ability to offer a variety of solutions that combine its own technologies with those of reputed international companies, to which it acts as distributor. It also profits from the visibility afforded by a series of innovation prizes as well by the engagement on several collective activities on behalf of the industry. This approach is also valid for the foreign market. However, in more distant markets (e.g. the US) the firm opts for licensing the technology to a local company that manufactures and sells it. Thus, the decision to ally with incumbents depends on their actual position in the value chain (and its potential benefits to the firm activities), as well as on the type of market addressed: alliances (including licensing of technology) are relatively more frequent in foreign markets and arms' length relations in the national market.

Finally the structure of relationships is clearly different in the case of WIND-SERV that operates in the large scale onshore wind segment, which is dominated by large incumbents (old and new players). In this case the new firm is a typical small specialised supplier of services that improve the performance of the incumbents' core business. Thus its activities provide value to the incumbents, but competition with them is unlikely given the different set of competences involved and the risk of expropriation is low because imitation is difficult, as was pointed out above. Moreover, since WINDSERV competencies are unique it operates in a niche where competition from similar companies is limited. The firm is not dependent on co-specialised complementary assets possessed by incumbents thus arms’ length commercial relationships prevail. But some long standing relationships exist with some important clients that have consistently included the firm in their wind plant installation projects. The uniqueness of its technology enabled WIND-SERV to expand to several foreign markets. Such expansion benefited from the interest of the incumbents in the firms' technology, since internationalisation (in particular in the early stages) was often conducted in the context of wind plant installation projects led by internationalized incumbents. These commercial partnerships were thus instrumental for the firms' penetration in some markets. Similarly to SOLAR, WIND-SERV draws some visibility from the participation of its entrepreneurs in a variety of activities for the promotion of the wind industry.

Table 6 summarises each case, providing a synthesis of the main features of the respective commercialisation process. 
Table 6 - Factors shaping commercialisation strategy: technology \& market conditions; commercialisation environment; incumbents' involvement

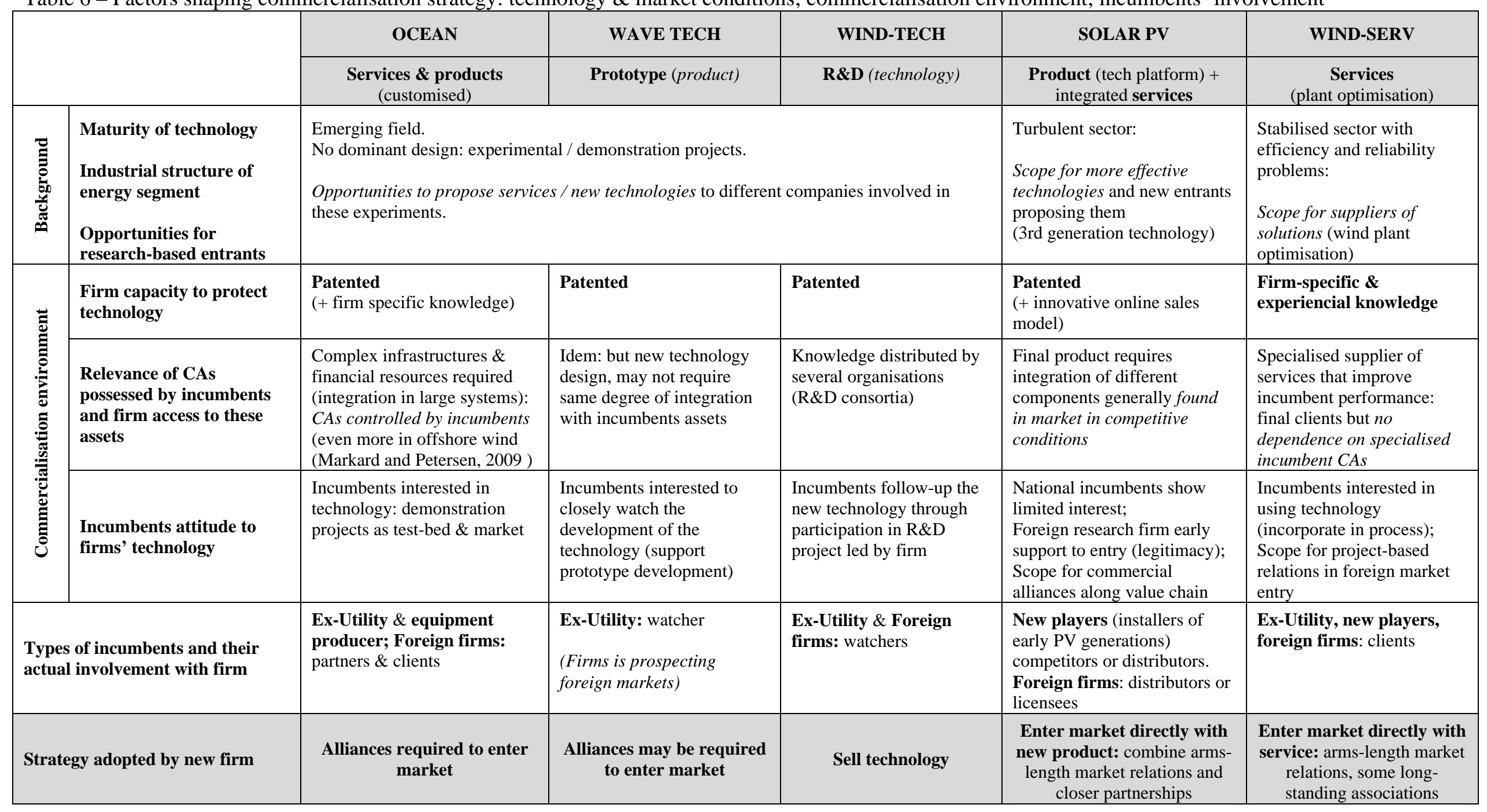


This exercise, enables us to uncover some sources of variation in the conditions experienced by the firms that can at least partly explain their positioning relatively to incumbents and thus the nature of the relationships established (or not) with them, in the commercialisation process. Drawing on this analysis we propose a categorisation for the two main dimensions that compose the "competitive environment” faced by the energy firms analysed and position these firms along them, as shown in Table 7. This framework can be subsequently applied to a wider set of firms, in order to assess whether it effectively fit the conditions faced by new entrants in the renewable energy sector.

Table 7 - Positioning of firms in case studies along the dimensions of the "competitive environment"

\begin{tabular}{|c|c|c|c|c|}
\hline & & \multicolumn{3}{|c|}{$\begin{array}{c}\text { Relevance of complementary assets } \\
\text { possessed by incumbents: } \\
\text { Firm access to complementary assets }\end{array}$} \\
\hline & & Skip & Access in market & $\begin{array}{c}\text { Controlled by } \\
\text { incumbents }\end{array}$ \\
\hline \multirow{3}{*}{$\begin{array}{l}\text { Relevance of } \\
\text { technology for } \\
\text { incumbents: } \\
\text { Incumbent } \\
\text { attitude }\end{array}$} & Watcher & WIND-TECH & & WAVE-TECH \\
\hline & $\begin{array}{l}\text { Interested in } \\
\text { development }\end{array}$ & & WIND-SERV & OCEAN $\vee$ \\
\hline & Competitor & & SOLAR & \\
\hline
\end{tabular}

\subsubsection{The attitude of incumbents relatively to the introduction of new energy technologies}

The analysis conducted in the previous section permitted us to identify three generic levels of involvement of incumbents in the process of exploitation of these technologies - they can simply keep a watch on the activities conducted by the developers of the new technologies; they can show a greater interest in their development, expressed through forms of direct participation or through the active or passive use of the resulting IP, products or services; finally they can be themselves involved in the development and/or commercialisation of competitor technologies. The two first levels are conducive to some form of cooperation between incumbents and new entrants, while in the third one there is competition between them.

In this section we look in greater detail to the positioning of incumbents relatively to the introduction of emerging energy technologies conducted by the firms analysed. As expected, established companies were found to be important players in all energy segments, although they did differ in their attitude and degree of involvement with the new technologies being introduced. Differences in incumbent behaviour emerged, as would be expected, relatively to technologies with different levels of maturity. But the analysis also revealed some diversity of behaviour among incumbents, namely regarding old vs. new players; energy producers vs. equipment manufacturers; national vs. foreign 
companies. Although the small number of cases makes the conclusion at this level largely exploratory, some regularities appear to start emerging from this preliminary assessment.

Table 8 summarises the main attitudes identified for each energy field/technology category and the type(s) of incumbents that adopted them, which are discussed in greater detail below. In order to characterise more precisely the incumbent behaviour, we start from the three types of incumbent involvement presented above to build a more detailed categorisation of attitudes:

- Watcher: incumbents keep an eye in the development of the technology and eventually provide some limited assistance to the firms introducing it.

- Investor: incumbents interested in the development of the technology who are more actively involved in the process of development, test or application, often engaging in technological and/or market relationships with the firms introducing the technology; in some cases they are also conducting own efforts in the field, to which the technology being introduced may be complementary.

- User: incumbents interested in the development of the technology who are not involved in the development/test of the technology (which may be distant from their own competences), but recognise its usefulness for their activities and therefore are clients for the technology (as licensees) and/or the products or services resulting from it; they can namely act as lead users for technologies still not fully stabilised.

- Competitor: incumbents are involved in the development or application of own technologies (earlier generations or alternative designs) to which the one being introduced acts as competitor.

Table 8 - Incumbents' attitude by energy field / type of technology

\begin{tabular}{|l|l|l|l|}
\hline & \multicolumn{1}{|c|}{ OCEAN } & \multicolumn{1}{c|}{ WIND } & \multicolumn{1}{c|}{ SOLAR } \\
\hline $\begin{array}{l}\text { Emerging } \\
\text { technology }\end{array}$ & $\begin{array}{l}\text { Incumbents (old): ex-utility; } \\
\text { equipment INVEST \& } \\
\text { WATCH } \\
\text { Leading international } \\
\text { companies - INVEST }\end{array}$ & $\begin{array}{l}\text { Incumbents (old): ex-Utility } \\
\text { - WATCH } \\
\text { Leading international } \\
\text { companies - WATCH }\end{array}$ & [no cases in the sample] \\
\hline $\begin{array}{l}\text { Developing } \\
\text { technology }\end{array}$ & & $\begin{array}{l}\text { Incumbents (old): ex-Utility } \\
\text { allied with foreign company } \\
\text { - INVEST }\end{array}$ & $\begin{array}{l}\text { Foreign solar companies - } \\
\text { LEAD USER or LICENSEE } \\
\text { Incumbents: new players - } \\
\text { USER or COMPETITOR }\end{array}$ \\
\hline $\begin{array}{l}\text { Stabilised } \\
\text { technology }\end{array}$ & & $\begin{array}{l}\text { Incumbents: old and new } \\
\text { players - USER }\end{array}$ & \\
\hline
\end{tabular}

A comparison between energy fields/technologies shows that the ex-utility emerges as key partner to new firms introducing emerging technologies along what can be described as a "wind/ocean cluster". These are areas where the ex-utility has focused in its move into the renewable business and, indeed, they appear to be closer to its core advantages and operational competence (centralized electricity 
production and large scale power plants) and also to its knowledge base (e.g. kinetic energy, turbines). However, the level and types of involvement vary, depending on the field and/or on technology being exploited. Thus, in stabilized fields (such as onshore wind) it is user of efficiency solutions. In developing (offshore wind) or emerging (wave) fields, whose technology match its knowledge base and experience, it is investor in demonstration projects (sometimes in alliance with foreign leading companies in the area), providing a testing infrastructure or an experimental market for the new firm's products/skills. In emerging areas more distant from its core specialisation (high-altitude wind or new competitive wave technologies), it is watcher, through participation in research projects or the followup of technologies identified in ideas contests it promotes, including the support to early prototype development.

A similar behaviour can be identified in the case of the main national energy equipment producer, at least with respect to stabilized areas in the wind sector, or to new wind/ocean projects that match its core specialization, which are grounded on a comparable knowledge base and competitive advantage. However, it appears to be less interested in more exploratory projects in emerging fields that are distant from its core areas.

But there are major differences within this "wind/ocean cluster" relatively to the other incumbents: the new large players. With rare exceptions, they are absent from the ocean field and from emerging wind technologies, being specialized in large onshore wind systems. In this field they are basically clients for different types of efficiency solutions. Thus the relationship established with the researchbased firm is one of user-supplier.

There are also differences relatively to the role of foreign companies in the same cluster. In stabilised fields they operate in the country through subsidiaries and seem to behave as the local incumbents. In emerging fields, where research is still exploratory, some of them appear to be similarly interested in watching the firms' activities through involvement in joint research projects. But in emerging fields where technologies are being tested through demonstration projects - like wave and offshore wind some leading international companies are important partners, providing alternative test environments and markets and permitting the firms to expand their business beyond the local players. Local incumbent projects that involve foreign partners are often instrumental for enabling the connection between relevant international companies and the new firms.

The availability, at this stage, of only one case in solar PV, and also the absence of firms that are exploiting the new generations of cell technology, limits the conclusions that can be reached for this field. However, the information available suggests that the situation may be substantially different. 
In the case of the ex-utility we observe a marginal interest in the early demonstration of the new technology being introduced, that is not pursued. This attitude contrasts with the behaviour described above for the wind/ocean "cluster", but is consistent with a much more recent interest in solar PV and a focus large scale plants, that is patent in the company strategic documents. This suggests a much lower degree of involvement in the solar field and, in particular, in the distributed business, that is more distant from the centralized production regime. Large new players appear to have limited intervention in the actual development of new technologies. There is a group of technology intensive companies that are involved in the manufacturing of PV cells, but they do it under license from third parties. The remaining are essentially system integrators/plant installers, being mostly involved in process innovation ${ }^{10}$. However, some of them operate in the market for distributed systems and thus they can be users of the technologies being introduced (if they include the firms' products in their portfolio) or competitors (if they base it in alternative systems). In this particular case, actual interest in the technology commercialised by the new company only appeared to be present in the case of foreign companies. Although this case cannot be generalised, it is worth mentioning the presence of a solar research firm that acted as lead-user and assisted the new firm in the introduction of a new technology in an unfamiliar market. On the other hand, entry in some foreign markets was achieved through licensing contracts with companies operating in those markets that were sufficiently interested in the technology to manufacture and sell it. Thus, it was alliances with foreign companies that enabled the company to extend its activities to more distant locations.

\section{Conclusions and guidelines for subsequent research}

In this paper we have conducted an exploratory analysis of the process of commercialisation of emerging renewable energy technologies conducted by new research-based companies, based on a set of cases studies. Given the nature of the energy sector - that despite the on-going changes at the technological and business level, remains dominated by large companies - we focused on the relationships established by the new firms in the process of development and market introduction of their technologies, with particular emphasis on the relationships with incumbents.

These results obtained are obviously preliminary, but offer a first approach to our research questions and permit us to identify some issues that need to be further explored, thus providing some guidelines to the next stage of the research.

\footnotetext{
${ }^{10}$ The exceptions appear to be an energy equipment producer and a construction materials company that are currently involved in collaborative research and patenting with the university in the PV cells field, but are not yet in the market.
} 
Universities and other research organisations were found to be the main supplier of knowledge for all the firms studied, not only at start-up, but also over time for the continued development of new products (in the case of firms that had already introduced the first technology in the market). They were also a key source of legitimacy. This was transversal to all fields, reflecting the typical behaviour of research-based firms (Mustar et al. 2006). One important difference between firms operating in emerging and more stabilized fields concerned the scope of the networks relevant for knowledge access that were wider and more international in the case of the former; and the nature of the knowledge being accessed through them. In fact, firms exploiting in less mature technologies often relied on more fundamental research, which was often developed in the context of European RTD projects. Thus, their competiveness depended on their ability to connect to the networks formed in those contexts, which frequently also involved Portuguese universities.

However, the behaviour of the spin-offs studied depart from previous research, in what we find only a moderate relevance of the parent organisation. In most firms - and particularly those created by younger entrepreneurs - the technology was not developed in the context of the parent organisation and transferred to the new firm. Rather it was largely developed by the entrepreneurs, with contributions from the parent, but also from other research organisations that emerge as critical knowledge sources. Universities also play a number of other important roles, from physical incubation to access to a variety of resources of a technical or non-technical nature that considerably reduce the investment made by the new start-up. Although this type of "extended incubation" is equally typical of spin-offs (Clarysse et al, 2005), once again in several cases these roles are not necessarily played by the parent organisation. It is therefore relevant to understand whether this dilution of the role of the parent organisation and its early extension to a variety of other universities is also observed in other cases and emerges as a pattern in the energy or in some types of energy technologies. The fact that energy research is often highly multidisciplinary, involving contributions from different fields (that at least in the case of Portugal are often located in different teams), suggests that it may indeed be a trace of the field.

The extent to which the new firms rely on universities for access to a variety of resources besides knowledge, the fact that entrepreneurship programmes are the basic source of seed-capital for startups led by young scientists, as well as the high reliance on public funding - both national and European - for the development of technologies (and of actual products) points to a shortage of other sources of capital and also, in some cases, to the limited involvement of other actors as indirect sources of finance. This can be partly explained by the uncertainty still associated to some of the technologies being developed. But it also reflects the limited interest shown by venture capital in the field, as well as a dearth of corporate investment, which is sometimes presented as a mode of 
intervention of established firms in the new energy fields (Teppo and Wustenhagen, 2009) ${ }^{11}$. This extensive reliance on alternative sources of funding has been identified in other studies of Portuguese research spin-offs (Sousa et al, 2011). But in some other fields VC companies have already turned their attention to new firms with promising technologies. Thus, subsequent research should address the few firms that have so far received VC attention in order to understand whether these firms present some particular characteristics and well as if this introduces some differences in firms' development. It will also attempt to identify instances of corporate investment and inquire major players about their views on this mode of intervention.

The analysis of the process of market entry and the relationships established (or not) with incumbents for that purpose suggests that there are differences between energy fields in what concerns the interest of established companies in the technologies being introduced by the new firms and the role these companies play in their commercialisation. Those differences are not just related with the stage of development of the technology. They are also associated with the evolution of the different energy segments at country level, and with the strategies adopted by local (and also some foreign) firms relatively to each of them. This is likely to lead to differences in incumbents' actual perception of the relevance of the new technologies for their business and also to different field/technology focus of more technology-oriented incumbents (e.g. the contrast wind/ocean vs. solar). The position and attitude of incumbents is critical for new entrants in this sector, contributing to shape the competitive environment they face and thus to determine their decisions on the mode of exploitation of their technology. Thus, a better understanding of the incumbents' behaviour is a key element of our research. However, a more extensive analysis is necessary to have a clearer picture. This requires, first of all, the analysis of a larger number of cases in the solar field and the search for alternative technologies in wind or ocean, as well as the consideration of the actual strategies of more proactive incumbents.

On the other hand, since technology markets are often highly internationalised, it is also important to take into account the opportunities opened outside the national market, how they emerge and how they influence the decisions made by the firms. However, it is important to have in mind that an early internationalisation is not easy for small (often resource deprived) start-ups, which will always benefit from the possibility of making the first steps in the more familiar country environment, in particular in a sector where country-level policies and lobbies can offer additional entry barriers.

\footnotetext{
${ }^{11}$ The only large company in the energy field that has publicly announced the creation of a corporate venture fund was the energy utility, but it has not intervened so far in any of the research spin-offs identified (to the best of our knowledge).
} 
It is nevertheless evident from the results obtained that some incumbents - in particular those previously involved in the energy sector - are interested in some of the new technologies being introduced, even if sometimes only in a "watcher" position. The case of the energy utility is particularly worthy of note, since it not only keeps a watch on some emerging technologies that are distant from its core fields/competences, but proactively searches for new ideas and appears to be prepared to support/follow-up some of them. In addition, it is also worth taking in consideration the alternative offered by foreign companies interested in the technologies being developed. They emerge as particularly relevant in fields that are less advanced at country level. But can also play a role in fields in which local incumbents show interest, but where the foreign company can offer greater scope for exploitation and/or limit the threat of excessive dependence on one large partner.

Finally, it can also be concluded that when incumbents reveal an interest in the technology they can play important roles that range from contributing to shape the opportunity, "incubating” the company in the early stages, supporting the development and test the technology; offering an early market to it, affording legitimacy and facilitating access to business networks. This paper focused mainly on the presence/absence of incumbents and their type of intervention and put less emphasis on the way the new firms perceive and manage the relationships with the large partners, as well as the actual strategies they deploy to obtain the partnerships, to mobilize them for firm purposes and/or to defend themselves from their negative aspects. Subsequent research will resort to the rich information that was obtained on these issues to examine the relationship more thoroughly, from the spin-off point of view.

These first results permit us to define some guidelines for further research. We are particularly interested in assessing whether the impressions presented above are confirmed when a larger and more varied set of firms is considered. Thus, the next step is to extend the research to new cases, which are expected to provide additional insights both in terms of technology development (relationships focused on knowledge production and exchange) and in terms of its commercialisation.

Concerning the former we are interested in understanding whether differences in the nature of knowledge between energy fields (or specific technologies) have implications for the process of firm formation and, in particular, for the type of knowledge relationships established and the role played by different organisations. Concerning the latter we are interested in defining more precisely the different commercialisation environments that are likley to be present in the renewable energy sector and to explore their impact upon the strategic decisions made by new research-based entrant.

Finally, we are also interested in identifying the main determinants of the differences in the modes of incumbent intervention. In particular we will be interested in exploring in more detail some ideas that 
appear to emerge from these cases: a) differences between old incumbents and new players that point to a lower interest of the latter in the new technologies, and also potential differences in the type of intervention of energy producers vs. equipment manufacturers; b) the relationship between modes of incumbent intervention and field/type of technology; c) the watcher position adopted by some incumbents in fields that depart from their core specialization: which modes it assume; whether, when and in which conditions it is pursued beyond the early follow-up; d) incumbents as competitors: whether and in which conditions effective competition takes place and which are the implications for the firms; e) roles of partnerships with foreign companies: expand local market; compensate for local limitations; born global attitudes.

In order to pursue with these objectives we will conduct cases studies that fully cover the criteria set in the methods section and also take in consideration the gaps identified in this analysis. But we will also need to turn some attention to the actual incumbents, since an understanding of their intervention would be incomplete without attempting to elicit their view point. Thus the research will involve speaking with some key incumbents and conducting a detailed analysis of their strategic documents. It will also entail the identification and closer analysis of technology monitoring methods often employed by incumbents such as ideas contests, incubation facilities, venture funds or participation in R\&D consortia. Finally, we will consider the activity of venture capital and also attempt to collect their views and perspectives on the intervention in this type of firms.

\section{References}

Adler, P. and Kwon, S. (2002) Social capital: prospects for a new concept. Academy of Management Review, 27: 17-40.

Aggarwal, V. and Hsu ,D. (2009) Modes of cooperative R\&D commercialization by start-ups. Strategic Management Journal, 30: 835-864.

Anderson, A.R., Park, J. and Jack, S. (2007) Entrepreneurial social capital: conceptualizing social capital in new high-tech firms. International Small Business Journal, 25: 245-72.

Arenius, P. and De Clercq, D. (2005) A network-based approach on opportunity recognition. Small Business Economics, 24(3): 249-65.

Arora, A. and Merges, R. (2004) Specialized Supply Firms, Property Rights and Firm Boundaries. Industrial and Corporate Change, 13: 451-475.

Arora, A., Fosfuri, A. and Gambardella, A. (2001) Markets for technology and their implications for corporate strategies. Industrial and Corporate Change, 10(2): 419-51.

Arrow, K (1962) Economic Welfare and Allocation of Resources for Inventions”, in: R. Nelson (Ed) The Rate and Direction of Inventive Activity (Princeton University Press). 
Autio, M. (1997) New, Technology-based Firms in Innovation Networks Sympletic and Generative. Research Policy, 26: 263-281.

Ayari, N,. Blazsek, S. and Mendi, P. (2012) Renewable energy innovations in Europe: a dynamic panel data approach. Applied Economics, 44(24): 3135-3147.

Brown J.E., Hendry, C.N. and Harborne, P. (2007) Developing Radical Technology for Sustainable Energy Markets: The Role of New Small Firms. International Small Business Journal, 25(6): 603630.

Carvalho, D., Wemans,J., Lima, J. and Malico, I. (2011) Photovoltaic energy mini-generation: Future perspectives for Portugal. Energy Policy, 39(9): 5465-5473.

Choi, Y.R. and Shepherd, D.A. (2005) Stakeholder perceptions of age and other dimensions of newness. Journal of Management, 31(4): 573-96.

Ciabuschi, F., Perna, A. and Snehota, I. (2011) Assembling Resources in the Formation of a New Business. Journal of Business Research, 65: 220-229

Clarysse, B., Wright, M., Lockett, A., van de Velde, E. and Vohora, A. (2005) Spinning out new ventures: a typology of incubation strategies from European research institutions. Journal of Business Venturing, 20 (2): 183-216.

Colombo, M., Grilli, L. and Piva, E. (2006) In search of complementary assets: the determinants of alliance formation of high-tech start-ups. Research Policy, 35: 1166-99.

Conceição, O., Fontes, M. and Calapez, T. (2012) The commercialisation decisions of research-based spin-offs: targeting the market for technologies. Technovation, 32: 43-56.

Darmstadter, J. (2003) The Economic and Policy Setting of Renewable Energy: Where Do Things Stand? RFF Discussion Paper 03-64.

Dewald, U. and Truffer, B. (2011) Market Formation in Technological Innovation SystemsDiffusion of Photovoltaic Applications in Germany, Industry and Innovation, 18; 285-300.

DGEE (2012) Linhas de orientação para a revisão dos Planos Nacionais de Ação para as Energias Renováveis e para a Eficiência Energética, Direç̧ão Geral de Energia e Geologia, Abril 2012.

Duncan, R. (2010) Renewable Energy and the Utility: The Next 20 Years. Renewable Energy World 2(3).

Dyerson, R. and Pilkington, A. (2005) Gales of Creative Destruction and the Opportunistic Hurricane: the case of Electric Vehicles in California. Technology Analysis and Strategic Management, 17(4): 391-408.

Elfring, T. and Hulsink, W. (2003) Networks in entrepreneurship: the case of high-technology firms. Small Business Economics, 21: 409-422.

Ensley, M.D. and Hmieleski, K.M. (2005) A comparative study of new venture top management team composition, dynamics and performance between university-based and independent start-ups. Research Policy, 34(7): 1091-105. 
Foxon, T.J., Hammond, G.P. and Pearson, P.J.G. (2010) Developing transition pathways for a low carbon electricity system in the UK. Technological Forecasting \& Social Change, 77(8): 120-1213.

Gans, J. and Stern, S. (2003) The product market and the market for "ideas": commercialisation strategies for technology entrepreneurs. Research Policy, 32: 333- 50.

Gans, J., Hsu, D.H., and Stern, S. (2002) When Does Start-up Innovation Spur the Gale of Creative Destruction? Rand Journal of Economics, 33, pp. 571-586.

Garud, R. and Karnöe, P. (2003) Bricolage versus breakthrough: distributed and embedded agency in technology entrepreneurship. Research Policy, 32(2): 277-300.

Gawer A, and Cusumano M.A. (2008) How Companies Become Platform Leaders., MIT Sloan Management Review, 49: 28-35.

Geels, F. W. (2002) Technological transitions as evolutionary reconfiguration processes: a ulti-level perspective and a case study. Research Policy, 31(8-9): 1257-1274.

Geels, F. W. and J. Schot (2007) Typology of sociotechnical transition pathways, Research Policy, 36: 399-417.

Gilsing, V.A. and G.M. Duysters (2008) Understanding novelty creation in exploration networksStructural and relational embeddedness jointly considered, Technovation 28: 693-708.

Gottinger, H. and Umali, C. (2011) Organizational entrepreneurship: a historical overview on industry alliances in biotech and pharmaceuticals. The Open Business Journal, 4: 14-27.

Greve, A. and Salaff, J.W. (2003) Social networks and entrepreneurship, Entrepreneurship Theory and Practice, 28: 1-22.

Grimaldi, R. and Grandi, A. (2003) Exploring the networking characteristics of new venture founding teams: a study of Italian academic spin-offs, Small Business Economics, 21: 329-341.

Grimaldi, R. and Torrisi, S. (2001) Codified-tacit and general-specific knowledge in the division of labour among firms: a study of the software industry. Research Policy, 30(9): 1425-42

Hekkert, M., Suurs, R., Negro, S., Kuhlmann, S. and Smits, R. (2007) Functions of innovation systems: A new approach for analysing technological change. Technological Forecasting and Social Change, 74(4): p. 413-432.

Hekkert, M.P. and Negro, S.O. (2009) Functions of innovation systems as a framework to understand sustainable technological change: Empirical evidence for earlier claims. Technological Forecasting and Social Change, 76 (4): 584-594.

Hendry C.N., Harborne, P. and Brown, J. E. (2007) Niche Entry as a Route to Mainstream Innovation: Learning from the Phosphoric Acid Fuel Cell in Stationary Power. Technology Analysis and Strategic Management, 19(4): 403-425

Hockerts, K. and Wüstenhagen, R. (2010) Greening Goliaths versus emerging Davids — Theorizing about the role of incumbents and new entrants in sustainable entrepreneurship, Journal of Business Venturing, 25: 481-492. 
Hurmelinna-Laukkanen, P and Puumalainen, K. (2007) The nature and dynamics of appropriability Strategies for appropriating returns on innovation”, R\&D Management, 37, pp. 95-112.

IEA (2011a) Key World Energy Statistics, International Energy Agency.

IEA (2011b) Trends In Photovoltaic Applications, Survey report of selected IEA countries between 1992 and 2010, Report IEA-PVPS T1-20:2011.

IPCC (2011) IPCC Special Report on Renewable Energy Sources and Climate Change Mitigation. Prepared by Working Group III of the Intergovernmental Panel on Climate Change, Cambridge University Press, Cambridge, United Kingdom and New York, NY, USA, http://srren.ipccwg3.de/report/IPCC_SRREN_Full_Report.pdf.

Jacobsson, S. and Bergek, A. (2004): Transforming the energy sector: the evolution of technological systems in renewable energy technology. Industrial and Corporate Change, 13(5): 815-849.

Jacobsson, S., Sandén, B.A and Bångens, L (2004) Transforming the energy system - the evolution of the German technological system for solar cells. Technology Analysis and Strategic Management, 16: 3-30.

Jäger-Waldau, A. Szabó, M., Scarlat, N. and Monforti-Ferrario, F. (2011) Renewable electricity in Europe. Renewable and Sustainable Energy Reviews, 15: 3703-3716.

Johnstone, N. Hascic, I. and Popp, D. (2010) Renewable Energy Policies and Technological Innovation: Evidence Based on Patent Counts, Environ Resource Econ (2010) 45:133-155

Kaldellis, J. K., and Zafirakis, D. (2011) The wind energy (r)evolution: A short review of a long history. Renewable Energy, 36: 1887-1901.

Kay, L. (2012) Opportunities and Challenges in the Use of Innovation Prizes as a Government Policy Instrument, Minerva, 50:191-196

Kirkegaard, J.F., Hanemann, T., Weischer, L. and Miller, M. (2010) Toward a Sunny Future? Global Integration in the Solar PV Industry, Working Paper 10-6, Peterson Institute for International Economics.

Kishna. M.J., Negro, S. and Hekkert, M., (2011) Uncovering the strategies of environmentaltechnology entrepreneurs, paper presented at the DIME-DRUID ACADEMY Winter Conference 2011, Aalborg, Denmark, 20-22 January 2011, http://www2.druid.dk/conferences/viewpaper.php? $\mathrm{id}=502441 \& \mathrm{cf}=47$.

Klevorick, A., Levin, R.C., Nelson, R.R and Winter, S.G. (1995) On the Sources and Significance of Interindustry Differences in Technological Opportunities. Research Policy, 24: 185-205.

Landry, R., Amara, N., Rherrad, I. (2006) Why are some university researchers more likely to create spin-offs than others? Evidence from Canadian universities. Research Policy. 35(10): 1599-1615

Lerner, J. and Merges, R.P. (1998) The control of technology alliances: an empirical analysis of the biotechnology industry. Journal of Industrial Economics, 46(2): 125-56.

Levinthal, D. (1997) Adaptation on Rugged Landscapes. Management Science, 43: 934-950. 
Luo, X.R., Koput, K.W. and Powell, W.. (2009) Intellectual capital or signal? The effects of scientists on alliance formation in knowledge-intensive industries. Research Policy, 38(8): 1313-25.

Markard J. and Petersen, R. (2009) The offshore trend: Structural changes in the wind power sector, Energy Policy, 37: 3545-3556.

Markard J. and Truffer, B. (2008) Technological innovation systems and the multi-level perspective: towards an integrated framework. Research Policy, 37: 596-615.

Mangematin V, Lemarié S, Boissin JP, Catherine D, Corolleur F, Coronini R and Trommetter M (2002) Development of SMEs and Heterogeneity of Trajectories: The Case of Biotechnology in France. Research Policy 32: 621-638.

McMillan, G., Narin, F. and Deeds, D. (2000) An analysis of the critical role of public science in innovation. The case of biotechnology. Research Policy, 29(1): 1-8.

MEID, 2010 - RE.NEW.ABLE. A Inspirar Portugal - Plano Novas Energias 2020 (ENE 2020). Lisboa: Ministério da Economia, Inovação e Desenvolvimento.

Moensted, M. (2007) Strategic networking in small high-tech firms. International Entreprise and Management Journal, 3(1): 15-27.

Musiolik, J. and Markard, J. (2011) Creating and shaping innovation systems: Formal networks in the innovation system for stationary fuel cells in Germany, Energy Policy 39: 1909-1922.

Mustar, P., Renault, M., Colombo, M., Piva, E., Fontes, M., Lockett, A., Wright, M., Clarysse, B. and Moray, N. (2006) Conceptualising the heterogeneity of research-based spin-offs: a multidimensional taxonomy, Research Policy, 35(2): 289-308.

Negro, S. and Hekkert, M. (2010) Seven typical system failures that hamper the diffusion of sustainable energy technologies. Paper presented at the International Schumpeter Society Conference 2010, Aalborg, June 21-24, 2010

Orsenigo, L. (1989) The Emergence of Biotechnology: institutions and markets in industrial innovation, London: Pinter Publishers.

Orsenigo, L., Pammolli, F. and Riccaboni, M. (2001) Technological Change and Network Dynamics. Lessons from the Pharmaceutical. Research Policy, 30: 485-508.

Plum, O., and Hassink, R., (2011) Comparing knowledge networking in different knowledge bases in Germany, Papers in Regional Science. 90(2), 355-372.

Rao, H. (1994) The social construction of reputation: Certification contests, legitimation, and the survival of organizations in the American automobile industry: 1895-1912. Strategic Management Journal, 15: 29-44.

Raven, R. (2007) Niche accumulation and Hybridisation strategies in transition processes towards a sustainable energy system. Energy Policy, 35(4): 2390-2400.

REN21 (2011) Renewables 2011 Global Status Report, Renewable Energy Policy Network for the 21st Century, Paris: REN Secretariat. 
Rothaermel, F.T. (2001) Complementary assets, strategic alliances, and the incumbent's advantage: an empirical study of industry and firm effects in the biopharmaceutical industry. Research Policy, 30: 1235-51.

Rothaermel, F.T. (2002). Technological discontinuities and interfirm cooperation: what determines a start-up’s attractiveness as alliance partner?. IEEE Transactions on Engineering Management, 49: 388-397.

Rothaermel, F.T. and Hill, C.W.L. (2005) Technological discontinuities and complementary assets: a longitudinal study of industry and firm performance. Organization Science, 16(1): 52-70.

Salavisa, I. and M. Fontes (2012) Social Networks, Innovation and the Knowledge Economy, Routledge (forthcoming)

Salavisa, I., Sousa, C. and Fontes, M. (2012) Topologies of innovation networks in knowledgeintensive sectors: Sectoral differences in the access to knowledge and complementary assets through formal and informal ties, Technovation (forthcoming).

Schoettl, J. and Lehmann-Ortega, L. (2010) Photovoltaic Business Models: Threat or Opportunity for Utilities?, in: R. Wüstenhagen, R. Wuebker (Eds.), Handbook of Research on Energy Entrepreneurship, Edward Elgar Publishing Ltd.

Schot, J. and Geels. F. (2007) Niches in evolutionary theories of technical change: A critical survey of the literature. Journal of Evolutionary Economics, 17:605-622.

Shan, W., Walker, G., Kogut, B. (1994) Interfirm cooperation and startup innovation in the biotechnology industry, Strategic Management Journal, 15: 387-94.

Shane, S. and Cable, D. (2002) Network ties, reputation and the financing of new ventures. Management Science, 48(3): 364-81.

Shane, S. and Stuart, T. (2002) Organizational endowments and the performance. Management Science, 48: 154-70.

Sine, W. and David, R.J (2003) Environmental jolts, institutional change, and the creation of entrepreneurial opportunity in the US electric power industry. Research Policy,32(2): 185-207.

Slotte-Kock, S. and Coviello, N. (2009) Entrepreneurship research on network processes: a review and ways forward, Entrepreneurship Theory and Practice, 34(1): 31-57

Smith, A., Stirling, A. and Berkhout, F. (2005) The governance of sustainable sociotechnical transitions. Research Policy, 34: 1491-1510.

Sousa, C., Videira, P. and Fontes, M. (2011) The role of entrepreneurs' social networks in the creation and early development of biotechnology companies, International Journal of Entrepreneurship and Small Business, 12(2): 227-44.

Stuart, T.E., Ozdemir, S.Z. and Ding, W.W. (2007) Vertical alliance networks: the case of universitybiotechnology-pharmaceutical alliance chains. Research Policy, 36: 477-98.

Teece, D.J. (1986) Profiting from technological innovation: implications for integration, collaboration, licensing and public policy. Research Policy, 15: 285-305. 
Teppo, T. and Wüstenhagen, R (2009) Why corporate venture capital funds fail - evidence from the European energy industry, World Review of Entrepreneurship, Management and Sustainable Development, 5(4): 353-375.

Verbong, G. and F. Geels (2010) Exploring sustainability transitions in the electricity sector with socio-technical pathways. Technological Forecasting \& Social Change, 77: 1214-1221.

Verbong, G.P.J. and Geels, F.W. (2007) The ongoing energy transition: Lessons from a sociotechnical, multi-level analysis of the Dutch electricity system (1960-2004). Energy Policy, 35(2): 1025-1037.

Vohora, A., Wright, M., Lockett, A. (2004) Critical junctures in the growth in university high-tech spinout companies. Research Policy, 33: 147-175.

Walsh, S., Kirchhoff, B.A.and Newbert, S. (2002) Differentiating Market Strategies for Disruptive Technologies. IEEE Transactions on Engineering Management, 49(4): 341-351.

WAVEC (2009) Ocean Energy: State of the Art, Lisbon: Wave Energy Centre [http://www.wavec.org/

client/files/April_2010_Report_State_of_Art_Ocean_Energy_efm_reduced.pdf]

Welter, F. (2011) Contextualizing Entrepreneurship - Conceptual Challenges and Ways Forward. Entrepreneurship Theory and Practice, 35(1): 165-184.

Winter, S. G. (1984) Schumpeterian competition in alternative technological regimes. Journal of Economic Behavior and Organization, 5: 287-320.

Witt, U. and Zellner, C. (2007) How firm organizations adapt to secure a sustained knowledge transfer?. Economics of Innovation and New Technology, 18(7): 647-61.

Wüstenhagen, R. and Wuebker (2010) An introduction to energy entrepreneurship research, in R. Wüstenhagen, R. Wuebker (Eds.), Handbook of Research on Energy Entrepreneurship, Edward Elgar Publishing, pp. 1-18.

Yli-Renko, H., Autio, E. and Sapienza, H.J. (2001) Social capital, knowledge acquisition, and knowledge exploitation in young technology-based firms. Strategic Management Journal, 22: 587613. 